\title{
Bir Müfessir Olarak Süddî el-Kebîr
}

\author{
Yrd. Doç. Dr. Nurullah DENiZER*
}

Atıf / @)- Denizer, N. (2017). Bir Müfessir Olarak Süddî el-Kebîr, Çukurova Üniversitesi Ilahiyat Fakültesi Dergisi, 17 (1), 357-388.

Öz- Tefsir ilmi, Kur'ân'ın nâzil olmaya başlaması ile birlikte ve Hz. Peygamberin kendisine vahyedilen ayetleri insanlara tebliği ve gerekli yerleri açıklaması suretiyle tatbiki olarak başlamıştır. Hz. Peygamber'in vefatından sonra sahabîler Kur'ân'a dair Hz. Peygamber'den öğrendikleri bilgileri gerek sadece naklederek gerekse yorumlamak suretiyle kendilerinden sonraki nesil olan tâbiîlere aktarmışlardır. Tâbiîn dönemi, İslam topraklarının genişlemesi, farklı ırk ve kültürden olan insanların da İslam'ı kabul etmesiyle birlikte ortaya çıkan yeni soru ve sorunların Kur'ân ışığında anlaşılması ve yorumlanmasına dair farklı yaklaşımların tezahür ettiği bir dönemdir. Bu dönemde Mekke, Medine ve Kûfe'de oluşan tefsir medreselerinde yetişen tâbiîler, sahabîlerden aldıkları bilgiler ışığında Kur'ân'ın anlaşılması ve uygulanması hususunda yöntem olarak birbirlerinden ayrışmaya başlamışlardır. Ayrıca bu dönem, tefsire dair bilgilerin müstakil risaleler halinde telif edilmeye başlandığı bir zaman dilimidir. Süddî el-Kebîr de Hicaz'da doğmuş Kûfe'de yaşamış ve tefsire dair naklettiği pek çok rivayetle sonraki dönem müfessirlerine kaynaklık etmiş tâbiînin önde gelen şahsiyetlerinden birisidir. Bilhassa Ibn Abbas ve Ibn Mes'ûd'dan nakillerde bulunan Süddînin kendisine atfedilen tam bir tefsirinden kaynaklarda bahsedilse de günümüze ulaşan bu vasıfta bir eser bulunmamaktadır. Süddî'den gelen tefsir rivayetleri, bilhassa rivayet tefsirleri içerisinde dağınık olarak yer almaktadır. Bu rivayetler incelendiğinde onun, Kur'ân'ı Kur'ân ve sünnet ile tefsir yöntemlerini kullandığı, nüzul sebepleri ve tarihî bilgilerden istifade ettiği, yer yer şeri hükümler çıkardığı, nesh ve müteşabih gibi konularda fikir beyan ettiği görülmektedir. Naklettiği rivayetlerde Süddî'nin en çok eleştiri aldığı nokta ise isrâiliyyâta yoğun bir şekilde yer vermesidir. Bu çalışmada Süddî'nin hayatı, ilmî yönü ve hakkındaki Şîilik iddiaları değerlendirilecek, kendisinden gelen tefsir rivayetleri ekseninde onun tefsir yöntemi ve müfessir yönü ortaya konulmaya çalışılacaktır.

Anahtar sözcükler- Tefsir, rivayet tefsiri, yöntem, Süddî

\section{$\S \S \S$}

Makalenin gelişi: 02.05.2017; Yayına kabul tarihi: 19.06.2017

* Uşak Üniversitesi İslami İlimler Fakültesi Tefsir Anabilim Dalı, e-posta: nurullah.denizer@usak.edu.tr 


\section{Giriş}

Tâbiîler Hz. Peygamber'in, "İnsanların en hayırlısı benim asrımda olanlar, sonra onları takip edenler, sonra onları takip edenlerdir."1 diyerek övdüğü ve Kur'ân'ın anlaşılması ve sonraki nesillere aktarılması hususunda önemli rol üstlenen bir nesildir. Tâbiîler gerek Hicaz'daki gerekse genişleyen İslam topraklarının çeşitli beldelerine yerleşen sahabîlerden ders almışlar ve onlardan öğrendikleri bilgileri sonraki nesillere aktaran bir köprü vazifesi görmüşlerdir. Hızla genişleyen İslam coğrafyasının farklı bölgelerinde ashab, Kur'ân'ı ve Hz. Peygamber'den öğrendiklerini bu beldelerdeki yeni Müslümanlara öğretmiş ve buralarda ilim halkaları oluşturmuşlardır. İslam toplumu içerisinde etnik ve kültürel farklılıkların artması, Müslümanların farklı soru ve sorunlarla karşılaşmalarına sebep olmuş ve bunun neticesinde Kur'ân tefsirinde farklı yöntemlerin kullanıldığı tefsir medreseleri teşekkül etmiştir. Bu medreselerde ashabtan ders alan tâbiîler özellikle hadis ve tefsir alanında önemli hizmetler vermişler ve bu ilimlerin yazıya geçirilmesi faaliyetinin ilk adımlarını atmışlardır. Ayrıca tefsir ilmi açısından bakıldığında bu dönem; Kur'ân'ı anlama ve yorumlama faaliyetindeki yöntem çeşitliliğinin Mekke, Medine ve Kûfe medreselerinde sistematik bir şekilde ilk defa ayrıştığı bir dönem olarak değerlendirilebilir. Bu çalışmada müfessir yönünü ele alacağımız Süddî, nakle verdiği öncelik ve önemle bilinen Mekke ve Medine medreselerinin bulunduğu Hicaz'da doğması ve re'y ile tefsire verdiği önem ile temayüz etmiş Kûfe'de yaşaması bakımından tefsir ilmi açısından önemli bir konumda yer almaktadır.

\section{Süddî el-Kebîr'in (v. 127/745) Hayatı, İlmi ve Şahsiyeti}

\section{1. İsmi ve Soyu}

Süddî̀nin tam adı, İsmail b. Abdirrahman b. Ebî Kerîme es-Süddî elKebîr'dir ve Kureyş'in reisi Zeyneb binti Kays b. Mahreme el-Muttalibî b. Abdu Menaf b. Kusayy'ın mevlâsıdır. Künyesi Ebû Muhammed'dir. Süddî'nin künyesi ve babasının ismi ile ilgili bir ihtilaf olmamakla beraber onun soyu hakkında bazı tartışmalar mevcuttur. Buhârî ve İbn Hacer, Süddî'nin atalarını 'İsmail b. Abdurrahman b. Ebî Kerîme' şeklinde sıralarken², İbn Hıbbân el-Büstî, İbnü'l-Esîr ve Yâkût el-Hamevî bu sıralamayı 'İsmail b. Abdurrahman b. Ebî

1 Müslim, Ebû Huseyn Müslim b. Haccâc el-Kuşeyrî, Sahîh, Dâru Tayyibe, Riyad, 426, Fedâil, 52.

2 İbn Hacer Askalânî Ebu'l-Fazl Şihâbuddîn Ahmed, Tehzîbu't-Tehzîb, Dâru'l-Fikr, Beyrut, 1984, VI, 232; İbn Ebî Hâtim, Ebû Muhammed Abdurrahman b. Muhammed b. İdrîs, el-Cerh ve't-Ta'dîl, Dâru İhyâi't-Turâsi'l-Arabî, Beyrut, 1952, II, 184. 
Züeyb' şeklinde tayin etmişlerdir. ${ }^{3}$ Her ne kadar Hicaz da doğmuş olsa da Süddî'nin Hicazla olan ilişkisi, kölelik ve doğum yeri bakımından olmalıdır. Zira kaynaklarda babasının, İsfahan'ın önde gelen kimselerinden olduğu zikredilmektedir. ${ }^{4}$

Onun 'Süddî' ismi ile anılması hususunda da bir takım görüş farklılıkları söz konusudur. Bir görüşe göre Süddî, Kûfe'deki büyük mescidin eşiğinde oturup orada başörtüsü sattığından dolayı 'Süddî' olarak meşhur olmuştur ki yaygın olan görüş de budur. ${ }^{6}$ Diğer bir görüşe göre ise Süddî, şehrin 'Südd' yahut 'Südde' denilen bir mevkisinde ikamet ettiği için, bu yere nisbetle Süddî olarak anılmaktadır. ${ }^{7}$

\subsection{Doğumu Ve Vefati}

Süddî'nin doğum tarihi hakkında kaynaklarda net bir bilgi mevcut değildir. Tam bir tarih verememekle beraber kaynaklar; Süddî'nin, sahabeden Hasan b. Ali, Sa'd b. Ebî Vakkas, Ebû Hureyre, İbn-i Abbas, İbn-i Ömer ve Ebû Sa'îd el-Hudrî ile görüştüğünü bildirmekte ancak bu görüşmelerin ne

3 İbn Hibban, Ebû Hâtim Muhammed b. Hibban b. Ahmed et-Temîmî, Meşahiru Ulemai'l-Emsâr, thk. Marzûk Alî İbrahim, Dâru'l-Vefâ, Mansûre, 1991, s. 178; İbnü'l-Esîr, Ebu'l-Hasan İzzeddin Ali b.Muhammed b. Abdülkerim, el-Lübab fî Tehzibi'l-Ensâb, Dâru Sâdır, Beyrut, t.y., II, 110.

4 İsfahânî, Ebû Nuaym Ahmed b. Abdullah b. İshak, Kitâbu Târîhi İsbahan: Zikru Ahbâri İsbahan, thk. Seyyid Kisrevî Hasan, Dâru'I-Kütübi'l-IIImiyye, Beyrut, 1990, I, 247.

5 'Südde' sözlükte, kapı, kapı eşiği, eşik, oturak yeri, oturulacak yer, divan anlamlarına gelmektedir. İbn Düreyd, Ebû Bekr Muhammed b. el-Hazm el-Ezdî elBasrî, Kitâbu Cemherati'l-Luga, thk. Remzi Münîr Ba'lebekî, Dâru'l-IIIm li'l-Melâyîn, Beyrut, 1987, I, 111; Cevherî, Ebû Nasr İsmâîl b. Hammâd, es-Sıhâh Tâcu'I-Lüga ve Sıhâhi'-Arabiyye, thk. Ahmed Abdulgafûr Attâr, Dâru'l-ilım li'I-Melâyîn, Beyrut, 1987, II, 486. Fîruzâbâdî, Ebu't-Tâhir Mecdüddîn Muhammed b. Ya'kûb b. Muhammed, el-Kâmûsu'l-Muhît, Müessesetü'r-Risâle, Beyrut, 2005, s. 287; Zebîdî, Muhammed Murtaza el-Huseynî, Tâcu'l-'Arûs min Cevâhiri'-Kâmûs, thk. Abdulazîz Matar, 2. bs., Kuveyt, 1994, VIII, 183; İbn Manzûr, Ebu'l-Fazl Cemâluddîn Muhammed b. Mükerrem el-Ifrikî, Lisânü'l-'Arab, Dâru Sâdır, Beyrut, t.y., III, 209.

6 Mervezî, Ebû Sa'd Abdülkerim b. Muhammed b. Mansur Sem'ânî, el-Ensâb, Dâiretü Maârifi'l-Osmâniyye, Haydarâbâd, 1962, VII, 109; Hazrecî, Ahmed b. Muhammed, Hulasatu Tezhîbi Tehzîbi'l-Kemâl fî Esmâi'r-Ricâl, thk. Abdulfettâh Ebû Gudde, Mektebetü'l-Matbûâti'l-İslâmiyye-Dâru'I-Beşâir, Haleb-Beyrut, 1416, s. 35; İbnü'l-Esîr, el-Lübab fî Tehzibi'l-Ensâb, II, 110.

7 İbn Kuteybe, Ebû Muhammed Abdullah b. Müslim b. Kuteybe Dîneverî, el-Maârif, thk. Servet Ukkâşe, Heyetü'l-Mısriyyeti'l-Âmme li'l-Kitâb, Kahire, 1992, s. 596; İbn Mâkûlâ, Ebû Nasr Sa'dülmelik Ali b. Hibetullah b. Ali, el-Ikmal fî Ref'i'l-Irtiyab ani'lMü'telif ve'l-Muhtelif mine'l-Esma ve'l-Küna ve'l-Ensâb, Dâru'l-Kütübi'l-IIlmiyye, Beyrut, 1990, IV, 568. 
zaman ve hangi mekânda olduğuna dair bir bilgi vermemektedirler. ${ }^{8}$ Kaynakların verdiği bu bilgiye dayanarak bir tahmin yürütülecek olursa, Süddî'nin yukarıda isimleri geçen sahabeler arasında en erken vefat eden Hasan b. Ali'nin vefat tarihi olan h. 49 yılından önce yaşamış olması gerekir. Buna göre Süddî, Sa'd b. Ebî Vakkas (v. h. 55) ile altı, Ebû Hureyre (v. h. 57) ile on, İbn-i Abbas (v. h. 68) ile on dokuz, Ebu Sa'îd el Hudrî (v. h. 74) ve İbn-i Ömer (v. h. 73) ile de yirmi beş yıl yahut bundan daha uzun müddet, aynı zamanda yaşamıştır.

Kaynaklar Süddî'nin doğum yerini Hicaz olarak belirtmişler, daha belirli bir mekân ismi zikretmemişlerdir. Bununla birlikte onun, babasından naklettiği, "Zeyneb bint Kays Hz. Peygamber (s.a.s.) ile birlikte her iki kıbleye doğru da namaz kılmıştı."9 haberinden hareketle onun Medine'de doğduğu ve büyüdüğü söylenebilir. Zira kıblenin Mescid-i Aksa'dan Kâbe'ye çevrilmesi, Mekke'nin fethinden önce Medine'de gerçekleşmiştir. Ayrıca Süddî'nin görüştüğü ve haber rivayet ettiği sahâbîlerin Medine'de bulunmaları da, onun Medine'de büyüdüğü görüşünü desteklemektedir.

Süddî, Emevîler döneminde Mervan b. Muhammed'in hilafeti sırasında h. 127 veya h. 128 yılında Irak'ta vefat etmiştir. ${ }^{10}$

\section{3. İslam Beldelerine Seyahatleri}

Süddî hayatı boyunca, doğduğu Hicaz bölgesinde kalmak yerine; dinî, ilmî, edebî, fikrî ve ticarî hareketlerin önemli bir merkezi olan Kûfe'ye göç etti. Süddî Kûfe'de, geçimini temin etmek için ticaretle uğraşmış, ayrıca Kûfe'deki tefsir ulemasıyla irtibata geçerek Kur'ân tefsiri ile meşgul olmuştur. ${ }^{11}$

Bu devirde Kûfe'deki siyasi hayat bir türlü istikrar kazanamamış ve Kûfe, isyan ve kargaşanın eksik olmadığı bir şehir haline gelmişti. ${ }^{12}$ Süddî bu karmaşanın ve siyasi olayların karşısında durmuş, bunların içine dâhil olmaktan kaçınmıştır. Ali b. Ebî Tâlib'in hilafetinden sonra Kûfe hilafet merkezi olmuş ve daha sonra da Şia mezhebinin merkezi haline gelmişti. Kûfe, ilmî faa-

8 İbn Hacer Askalanî, Tehzîbu't-Tehzîb, Dâru'l-Fikr, Beyrut, 1984, I, 273-274; Hamevî Ebû Abdullah Şihâbuddîn Yâkût b. Abdullah Yakut, Mu'cemu'l-Udebâ, thk. İhsân Abbâs, Dâru'l-Garbi'l-İslâmî, Beyrut, 1993, II, 724 .

9 İbn Abdilber, Ebû Ömer Cemaleddîn Yûsuf b. Abdullah b. Muhammed Kurtubî, elIsti'âb fî Ma'rifeti'l-Ashâb, thk. Ali Muhammed Bicâvî, Dâru'l-Cîl, Beyrut, t.y., IV, 1857.

10 İbnü'l-Esîr, el-Lübab fî Tehzibi'l-Ensâb, II, 110; Hamevî, Mu'cemu'l-Udebâ, II, 724.

11 Muhammed 'Atâ Yûsuf, Tefsîru's-Süddî el-Kebîr, Dâru'l-Vefâ, Mansûre, 1993, s. 20.

12 Halîf, Yusuf, Hayatü'ş-Şi'r fi'l-Kûfe ila Nihâyeti Karni's-Sâni li'l-Hicre, Dâru'l-Kitâbi'lArabî, Kahire, 1968, s. 200. 
liyetler açısından Hicaz'a göre daha ileri bir konumda olan ve fikrî cereyanların kaynaştığı bir yer idi. Burada ilimle meşgul olanlar, sıhhatine itimat edebilecekleri bir hadis bulamadıkları zaman re'ye ve kıyasa müracaat ederlerdi. ${ }^{13}$ Bu karışık fikrî ortama rağmen Süddî'nin tefsirine baktığımızda, daha sonra da belirteceğimiz gibi onun ne Şîa mezhebine bağlı olduğuna, ne de felsefi eğilimleri olduğuna dair herhangi bir işaret bulamamaktayız.

\subsection{Hocaları}

Süddî̀nin hocalarının başında İ̉n Abbas gelir. Süddî, İ̉n Abbas'ın ilminden yararlanmış ve tefsirinde İbn Abbas'tan nakiller yapmıştır. ${ }^{14}$ Süddî'nin İbn Abbas'tan istifadesi ondan işitmesi ve rivayet etmesine dayanmaktadır. Bu konuda kendisi, "Ben bunu İbn Abbas'tan aldım. Doğru ise de, yanlış ise de onun sözüdür." demiştir. ${ }^{15}$ Bununla birlikte onun bu beyanı, kendisinin sadece bir nakledici olarak algılanmasına yol açmamalıdır. Zira Süddî çoğunlukla, bir nakilde bulunmadan önce kendisi de bazı açıklamalar yapmaktadır. Örneğin "Ey ateş! İbrahim'e karşı serin ve esenlik ol' dedik." 16 ayetinin tefsirinde Süddî, Hz. İbrâhim'in ateşe atılması hazırlıklarına dair uzun sayılabilecek bilgiler verdikten sonra İbn Abbas'tan "Eğer ayette 'selâm' kavli zikredilmemiş olsaydı Hz. İbrahim soğuktan ölürdü." kavlini rivayet etmiştir. ${ }^{17}$

Süddî'nin bir diğer hocası da Abdullah. b. Mes'ûd'dur. Ancak Süddî, Abdullah b. Mes'ûd'dan, İbn Abbas'tan yararlandığı kadar faydalanamamış, istifadesi, sadece ondan nakiller yapmakla sınırlı kalmıştır. İbn Teymiyye'nin belirttiğine göre Süddî’nin tefsirindeki nakillerin çoğu İbn Abbas ve Abdullah b. Mes'ûd'a aittir. ${ }^{18}$ Bunların yanı sıra Süddî; Enes b. Malik ve Mürretü'lHemedânî'den bizzat işittiği haberleri aktarmış ${ }^{19}$, babası Abdurrahman b. Ebî Kerîme, Yahya b. 'Abbâd, Ebû Salih b. Bâzan, Saîd b. Ubeyde, Ebû Abdurrahman es-Sülemî , 'Atâ b. Rebah, 'Ikrime ${ }^{20}$, Abdu Hayr ${ }^{21}$ Kelbî, Dâvud b. Ebî

13 Cerrahoğlu, İsmail, Tefsir Usûlü, Türkiye Diyanet Vakfı Yayınları, Ankara, 1993, s. 237-238

14 İbnü'l-Esîr, el-Lübab fî Tehzibi'l-Ensâb, II, 110; İbn Hacer Askalanî, Tehzîbu’tTehzîb, I, 274.

15 Hamevî, Mu'cemu'l-Udebâ, II, 725.

16 Enbiya 21/69.

17 Taberî, Ebû Cafer İbn Cerîr Muhammed b. Cerîr b. Yezîd, Câmiul-Beyân fî Tefsiri'-Kur'ân, thk. Abdullah b. Abdulmuhsin et-Türkî, Dâru Hicr li't-Tıbâa ve'nNeşr, 2001, XVI, 306.

18 İbn Teymiyye, Ebu'l-Abbas Takıyyüddîn Ahmed b. Abdulhalîm, Mukaddime fî Usûli't-Tefsir, Dâru Mektebeti'l-Hayât, Beyrut, 1988, s. 41-42.

19 Buhârî, Ebû Abdullah Muhammed b. İsmail, et-Târîhu'l-Kebîr, Dâiretü'l-Meârifi'lOsmâniyye, Haydarabad, t.y., I, 361.

20 İbn Hacer Askalânî, Tehzîbu't-Tehzîb, I, 274. 
Hind, Hişâm b. 'Urve,'den nakillere de tefsirinde yer vermiştir. ${ }^{22}$ Yûsuf b. 'Adiyy, 'Alâ b. Amr, Ebû İbrahim et-Tercumânî, Süfyân es-Sevrî, Şu'be, Hasan b. Sâlih, Ebû Avâne, Ebû Bekr b. Ayyâş, Semmâk b. Harb, İsmail b. Ebî Hâlid, İsâ b. Ömer el-Hemedânî, Süleymân et-Teymî, Osmân b. Sâbit, Mâlik b. Muğavvel, Zeyd b. Ebî Enîse, Sellâm b. Selîm (Ebu'l-Ahvas), İsrâîl b. Yûnus, İsmail b. Ebî İshâk (Ebû İsrâîl) ve Ziyâd b. Hayseme gibi isimler de Süddî'den nakilde bulunmuşlardır. ${ }^{23}$

\section{5. İlmî Konumu}

Süddî tefsir ve hadis alanlarında oldukça yüksek mertebeye sahip ve Kûfeliler arasında tefsire dair en çok nakilde bulunan âlim bir kimse idi. ${ }^{24} \mathrm{Bu}$ harî'nin naklettiğine göre Yahya b. Ma'în "Süddî'yi hayırdan başka bir şeyle anan kimse görmedim” demiştir. ${ }^{25}$ Ancak Süddî'nin ilimdeki bu yüksek mertebesi, bazı kıskançlık kapılarının açılmasına neden olmuştur. Süddî hakkında, haksız bir şekilde iftira kapısını açan ilk kimse, çağdaşı Şa'bî'dir. Şa'bî, Süddî'nin Kur'ân konusunda cahil olduğunu söylemiştir ${ }^{26}$ ancak Buhârînnin bildirdiğine göre İsmail b. Ebû Halid -ki Şa‘bî ve Süddî’nin çağdaşı olan güvenilir bir kimsedir- Süddî'nin, Kur'ân'ı Şa'bî'den daha iyi bildiği görüşündedir. ${ }^{27}$

Süddî'nin aleyhinde sözler söyleyen ve onu kötüleyenlerden birisi de Cürcânî'dir. Cürcânî'nin dediğine göre Kûfe'de Süddî ve Kelbî olmak üzere iki yalancı vardır ki bunlardan birisi ölmüştür. ${ }^{28}$ Cürcânî'nin bu iddiası, onun da rivayetlerinde yalancılıkla itham edilmesi sebebiyle dikkate alınmayabilir. ${ }^{29}$ Diğer yandan bu yalancılık ithamları ile Süddî el-Kebîr'in değil, onun kız kardeşinin oğlu olan Muhammed b. Mervân es-Süddî es-Sağîr'in kast ediliyor olması da mümkündür. Zira muhaddisler, Süddî es-Sagîr'in kâzib olduğu ve

21 İbn Ebî Hâtim, el-Cerh ve't-Ta'dîl, II, 184.

22 Hamevî, Mu'cemu'l-Udebâ, II, 725.

23 Hamevî, Mu'cemu'l-Udebâ, II, 725; İbnü'l-Esîr, el-Lübab fî Tehzibi'l-Ensâb, II, 110; Askalanî, Tehzîbu't-Tehzîb, I, 274; İbn Ebî Hâtim, el-Cerh ve't-Ta'dîl, II, 184.

24 Cerrahoğlu, İsmail, "Süddî”, Türkiye Diyanet Vakfı İslam Ansiklopedisi, Türkiye Diyanet Vakfı Yayınları, İstanbul, 2010, XXXVIII, 17.

25 Buhârî, Sahîh, I, 361; İbn Ebî Hâtim, el-Cerh ve't-Ta'dîl, II, 184; Hamevî, Mu'cemu'l-Udebâ, II, 725. Bu eserde mezkûr söz, Yahyâ b. Sa'îd'den nakledilmiştir.

26 İbn Hacer Askalânî, Tehzîbu’t-Tehzîb, I, 274; Cürcânî, Ebû Ahmed Abdullah b. Adî, el-Kâmil fî Du'afâi'r-Rical, thk. Yahyâ Muhtâr Gazâvî, Dâru'l-Fikr, Beyrut, 1988, I, 276.

27 Buhârî, Sahîh, I, 361.

28 İbn Hacer Askalânî, Tehzîbu't-Tehzîb, I, 274.

29 İbn Hacer Askalânî, Lisânü'l-Mîzân, Müessesetü'l-A'lemî li’l-Matbûât, Beyrut, 1971, I, 259. 
ondan hadis alınmaması gerektiği hususunda görüş bildirmişlerdir. ${ }^{30}$ Cürcânî'den nakledilen Süddî'nin yalancı olduğuna dair haberde ise Süddî elKebîr'in mi yoksa Süddî es-Sagîr'in mi kast edildiğine dair bir kayıt bulunmamaktadır.

Süddî'nin yaptığı rivayetlerin güvenilirliği hususunda hadis otoritelerinin görüş birliği içerisinde olduğunu söylemek mümkün değildir. Hakkında yapılan değerlendirmeler, sika, zayıf, leyyin ve kâzib gibi geniş bir yelpaze içerisinde çeşitlilik arz eder bir niteliktedir. ${ }^{31}$ Yine de Buhârî ve Ahmed b. Hanbel'in kendisini sika olarak görmesi, Şu'be b. Haccâc ve Süfyân es-Sevrî gibi hadis ilminin önde gelen âlimlerinin Süddî’den nakilde bulunmaktan çekinmemeleri, onun güvenilirliği konusunda delil olacak önemli noktalardır.

\subsection{Kişiliği ve Özellikleri}

Süddî'nin dış görünüşü ile ilgili kaynakların bize sunduğu bilgi; onun, oturduğu zaman göğsünü örtecek kadar uzun bir sakalı olduğundan ibarettir. ${ }^{32}$

Kişiliğine gelince ise 0 , yüksek derecede ahlak ve edep sahibi salih bir kimse idi. Öyle ki hayâsı onu, kendisi hakkında söylenen mesnedsiz ve kıskançlık içeren sözlere karşılık vermekten dahi alıkoyardı. Hatta bir gün talebelerine tefsir dersi yaparken oraya gelen Şa'bî'nin kendisine ağır sözler söyleyerek hakaret ettiği, kendisinin ise bu sözlere bir karşılık vermediği rivayet edilmiştir. ${ }^{33}$

\subsection{Hakkındaki Şîilik İddiaları}

Süddî'nin Şîi olduğuna dair ilk iddia hicri sekizinci asrın ortalarında Zehebî tarafından "Süddî Şîi olmakla itham edilmiştir." şeklinde dile getirilmişken ${ }^{34}$, İbn Hacer el-Askalânî bu iddiaya iki rivayet ilave etmiştir. İbn Hacer'in Hüseyin b. Vâkıd'dan naklettiğine göre o, Süddî'ye bazı sorular sormak için gelmiş; tam yanından ayrılırken Süddî'nin Hz. Ebû Bekir ve Hz. Ömer hakkında kötü sözler söylediğini işitmiştir. Aynı şekilde 'Ukaylî'den de, Süddî'nin $\mathrm{Hz}$. Ebû Bekir ve Hz. Ömer'i diline doladığı rivayet edilmiştir. ${ }^{35}$ Farklı kaynaklarda da Süddî’nin Şîa'ya meylettiği söylense hatta adı Şîa'nın önde gelenlerinin yer

30 İbn Ebî Hâtim, el-Cerh ve't-Ta'dîl, VIII, 86.

31 Mizzî, Ebu'l-Haccac Cemaleddin Yusuf b. Abdurrahman b. Yusuf, Tehzibü'lKemâl fî Esmâi'r-Ricâl, thk. Beşşâr Avvâd Ma'rûf, Müessesetü'r-Risâle, Beyrut, 1980, III, 134-137.

32 Hamevî, Mu'cemu'l-Udebâ, II, 725.

33 Taberî, Câmiu'I-Beyân, I, 87; Cürcânî, el-Kâmil fî Du'afâi'r-Rical, I, 276.

34 Zehebî, Ebû Abdullah Şemseddîn Muhammed b. Ahmed b. Osman, Mîzânü'l-ítidâl fî Nakdi'r-Ricâl, Dâru'l-Kütübi'I-İlmiyye, Beyrut, 1995, I, 396.

35 İbn Hacer Askalânî, Tehzîbu't-Tehzîb, I, 274. 
verildiği tabakat eserlerinde Alî b. Hüseyin, Muhammed Bâkır ve Cafer esSâdık'ın ashabından olduğu zikredilse dahi bu iddiayı ispatlayacak sağlam bir delil bulunmamaktadır. ${ }^{36}$

Süddî'nin tefsire dair olan rivayetlerine bakınca da bu iddiayı destekleyecek mahiyette olmasa dahi, bağlantı kurulabilecek sadece tek bir rivayetin olduğu görülmektedir. "Arkalarından ne gök ne de yer ağladı. Onlara mühlet de verilmedi." 37 ayetinin tefsirinde Taberî'nin yaptığı rivayete göre Süddî bu ayet hakkında, "Hüseyin b. Ali katledildiği zaman gökyüzü ağladı, göz yaşları da kırmızıydı." şeklinde bir açıklama yapmıştır. ${ }^{38}$

\subsection{Eserleri}

1- Tefsîrü's-Süddî: İbn Nedim'in bu isimle tespit ettiği kitabın ${ }^{39}$ elimize ulaşıp ulaşmadığı bilinmemektedir. Ebû Ya'lâ el-Halîlî, Süddî'nin bu tefsirinin, ittifakla olmasa da talebesi Esbât b. Nasr el-Hemedânî tarafından rivayet edildiğinin söylendiğini belirterek, Süddî'nin tefsirinin, en faziletli tefsirlerden biri olduğuna işaret etmektedir. ${ }^{40}$ Muhammed 'Atâ Yusuf, altı ayrı rivayet tefsirinde Süddî'ye nisbet edilen rivayetleri bir araya getirerek neşretmiştir.

2- Kitâbu'n-Nâsih ve'l-Mensûh: İbnü'l-Cevzî, Süddî'ye ait bu isimde bir kitaptan söz etmektedir. ${ }^{41}$

3- el-Megâzî ve’s-Siyer: İbn Tağrîberdî, en-Nücûmu'z-Zahira fî Mülûkü Mısr ve'l-Kâhira adlı eserinde Süddî'ye bu isimde bir eser nispet etmektedir. ${ }^{42}$

36 Cuzcânî, İshak İbrâhim b. Yakub b. İshak es-Sa'di, Ahvâlürr-Ricâl, thk. Subhî elBedrî Samerraî, Müessesetü'r-Risâle, Beyrut 1985, I, 54; Muhsin Emin, Ebu Muhammed Seyyid Muhsin b. Abdilkerim b. Ali, A'yânü'ş-Şî‘a, Dâru't-Taarruf li'lMatbûât, Beyrut, 1983, I, 379-380.

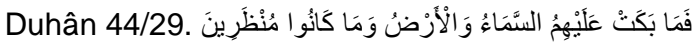
Taberî, Câmiu‘l-Beyân, XXI, 41. İbnü'n-Nedim, Ebu'l-Ferec Muhammed b. İshak, el-Fihrist, thk. İbrahim Ramazan, Dâru'I-Ma'rife, Beyrut, 1997, s. 53.

40 Kazvinî, Ebû Ya'la el-Halil b. Abdillah b. Ahmed el-Halîîi, el-İrşâd fî Ma'rifeti Ulûmi'lHadîs, Riyad, Mektebetü'r-Rüşd, 1989, s. 398.

41 İbnü'l-Cevzî, Abdurrahman b. Ali b. Abdullah, Nâsihu'l-Kur'ân ve Menâsihuhu, elCâmiatü'l-İslâmiyye, Medine, 2003, s. 104.

42 İbn Tağrîberdî, Cemaleddin Ebi'|-Muhasin Yûsuf el-Atabekî, en-Nücûmu'z-Zahira fî Mülûkü Mısr ve'l-Kâhira, Kahire, 1963, I, 308. 


\section{Süddî’nin Tefsirinin Özellikleri ve Yöntemi}

\section{1 Özellikleri}

\subsubsection{Kaynak Olması}

Süddî'nin İbn Mes'ûd ve İbn Abbas'tan aldığı rivayetlerle oluşan tefsirini, öğrencisi Esbât b. Nasrân el-Hemedânî rivayet etmektedir. Ebû Salih ve Ebû Mâlik vasıtalarıyla İbn-i Abbâs'a, Mürr vasıtasıyla da İbn Mes'ûd'a nispet edilen bu tefsiri Taberî, kendi tefsirinde mezkûr Esbât vasıtasıyla nakletmektedir. 43

Süddî'den tefsir ile ilgili gelen rivayetleri kullanan başlıca altı tefsir mevcuttur ve bu tefsirler kronolojik olarak şu şekilde sıralanabilir: Ebû Ca'fer Muhammed b. Cerîr et-Taberî (v. 310) Câmiu'l-Beyân 'an Te'vîli'l-Kur'ân, Ebû Abdullah Muhammed b. Ahmed el-Kurtubî (v. 671) el-Câmi' li-Ahkâmi'l-Kur'ân, İsmail b. Ömer b. Kesîr (v. 774) Tefsîru'l-Kur'âni'l-'Azîm, Celaleddin Suyûtî (v. 911) ed-Dürrü'l-Mensûr fi't-Tefsîr bi'l-Me'sûr, Muhammed b. Ali b. Abdullah eş-Şevkânî es-San'ânî (v. 1250) Fethu'l-Kadîr, Âlûsî (v. 1270) Rûhu'l-Meânî fî Tefsîri'l-Kur'âni'l-'Azîm ve's-Seb'u'l-Mesânî.

\subsubsection{Tam Bir Tefsir Olması}

Sahabe devri ve tabiîn devrinin ilk dönemlerine kadar Kur'ân tefsirine dair çalışmalar garîb, müşkil, mücmel ve mübhem lafızların açıklanması ve sebeb-i nüzûlü belirtmek gibi konularla sınırlıydı. Bu nedenle tefsir edilen ayetler, sadece bu konuları kapsayan ayetleri içeriyordu. Buna rağmen Süddî'nin tefsirinin, Kur'ân'ın çok az bir kısmı hariç tamamını içerdiği anlaşılmaktadır. İbn Nedîm el-Fihrist adlı eserinde Kitâbu Tefsîri's-Süddî adıyla bu eserden bahsetmiş ${ }^{44}$, Suyûtî de İtkân'da Süddî'nin tefsirinin emsalsiz bir tefsir olduğunu belirtmiştir. ${ }^{45}$ Fuad Sezgin de Süddî'nin tefsirinin Kur'ân'ın tamamını intiva ettiğini belirtmiştir. ${ }^{46}$ Bununla birlikte günümüze ulaşmış ve Süddî’ye nispet edilen tam tefsir mahiyetinde bir eser tespit edilememiştir. Süddî'den nakledilen tefsir rivayetlerinin miktarı fazla olsa da Kur'ân'ın tamamını kapsayacak mahiyette değildir.

43 Bilmen, Ömer Nasuhi, Büyük Tefsir Tarihi: Tabakâtü'l-Müfessirîn, Bilmen Yayınevi, İstanbul, 1973, I, 288-289.

44 İbnü'n-Nedim, el-Fihrist, s. 53.

45 Suyûtî, Celâleddîn Abdurrahmân, el-itkân fî 'Ulûmi'l-Kur'ân, thk. Muhammed Ebu'lFadl İbrahim, el-Mektebetü'l-'Asriyye, Beyrut, 1997, IV, 208.

46 Sezgin, Fuad, Târîhu't-Turâsi'l-Arabî, İdâretü's-Sekâfeti ve'n-Neşr bi'l-Câmia, Riyad, 1991, I, 77. 


\subsection{3. İbn Abbas'tan Etkilenmesi}

Süddî, İbn Abbas ile çağdaştır. Ondan ders almış, onun meclisinde bulunmuş ve ondan nakiller yapmıştır. ${ }^{47}$ İbn Abbas'ın tefsirdeki üstün mertebesi düşünülecek olursa, Süddî'nin, onun derslerinde bulunması ve ondan nakiller yapmasının önemi daha da artacak ve bu nedenle Süddî'nin, tefsirinde hocası İbn Abbas'tan etkilendiğini söylemek yanlış olmayacaktır. Tefsirlerde aynı rivayetlerin hem Süddî'ye hem de İbn Abbas'a nispet edilmesi, Süddî ve İbn Abbas arasındaki etkileşimi açıkça ortaya koymaktadır. Örneğin "Birbirinize düşman olarak (o cennetten) inin." 48 ayetinin tefsirinde bu ayetin muhataplarının Hz. Adem, Hz. Havva ve yılan olduğu rivayetini Taberî; İbn Vekî‘Mûsâ b. Hârûn-'Amr b. Hammâd el-Kannâd-Esbât-Süddî isnad zinciri ile verirken ${ }^{49}$, Suyûtî aynı haberi İbn Abbas'a dayandırmaktadır. 50 Aynı şekilde "Ben size, ben göklerin ve yerin gayblarını bilirim, sizin açıkladığınızı da, içinizde gizlediğinizi de bilirim dememiş miydim?"51 ayetinin tefsirinde de Taberî, İblis'in içinde sakladığı şeyin kibir olduğu haberini Süddî-Ebû Mâlik-İbn Abbas isnad zinciri ile zikrederken ${ }^{52}$ İbn Kesîr aynı haberi, hem aynı sened ile vererek hem de müstakil olarak Süddî’ye nispet ederek rivayet etmiştir. ${ }^{53} \mathrm{Bu}$ örneklerden Süddî'nin İbn Abbas'tan rivayette bulunduğu anlaşıldığı gibi sonraki âlimlerin bu rivayetleri müstakil olarak Süddî’ye atfetmek suretiyle karıştırdıkları sonucuna da varılabilir.

\subsubsection{Siyasi Gruplardan Etkilenmesi}

Hicrî ikinci asrın ortalarında, İslam'da ilk defa siyasi ayrılıklar zuhur etmiş; Havâric, Şia ve Mürcie gibi gruplar ortaya çıkmıştı. Bu siyasi yönelişlerin Süddî’yi de etkilediği ve bu etkilenmenin, onun tefsirine de yansıdığı söylenmektedir. Örneğin Hüseyin b. Vâkıd el-Mervezî Kur'ân'dan yetmiş ayetin tefsirini sormak için Süddî'nin yanına gittiğini, cevaplarını aldıktan sonra ayrılırken onun Hz. Ebu Bekir ile Hz. Ömer için kötü sözler söylediğini iddia etmiştir. ${ }^{54}$ Taberî, "Arkalarından ne gök, ne de yer ağladı. Onlara süre de verilme-

47 İbn Hacer Askalânî, Tehzîbu't-Tehzîb, I, 275.

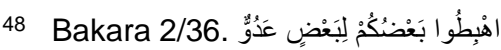

49 Taberî, Câmiu'I-Beyân, I, 572.

50 Suyûtî, Celâleddîn, ed-Dürrü'l-Mensûr fi't-Tefsîr bi'l-Me'sûr, thk. Abdullah Abdilmuhsin et-Türkî, Merkezi Hicr li'l-Buhûs ve'd-Dirâseti'l-Arabiyye ve'l-İslâmiyye, Kahire, 2003, I, 294.

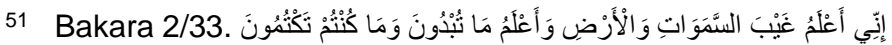

52 Taberî, Câmiu I-Beyân, I, 531.

53 İbn Kesîr, Ebû'l-Fidâ İsmâil b. Kesîr el-Kuraşî, Tefsîru'l-Kur'âni'l-Azîm, thk. Sâmî b. Muhammed es-Sellâme, Dâru Tayyibe, Riyad, 1999, I, 226.

54 Cuzcânî, Ahvâlürr-Ricâl, I, 54. 
di" 55 ayetinin tefsirini yaparken Muhammed b. İsmail-Abdurrahman b. Ebû Hammâd-Hakem b. Zahîr-Süddî şeklinde rivayet zincirini saydıktan sonra Süddî'den şu sözü nakleder: "Hüseyin b. Ali (r. a.) katledildiği zaman gökyüzü ağladı ve yağmur kırmızı yağdı."56

Suyûtî de "Bizden iyi kimseler olduğu gibi, iyi olmayanlar da var. Biz türlü türlü yollar tutmuşuz" 57 ayetinin tefsirinde Süddî'den naklen şu açıklamayı yapmıştır: "Yani cinler; Kaderiye, Mürcie, Şia ve Rafızî gibi gruplara bölünmüşlerdi" 58

Tefsirlerde geçen bu ve bunun gibi rivayetlere rağmen Süddî'nin tefsiri dikkatli bir şekilde incelendiğinde, Süddî'nin, bu siyasi fırkalardan hiç birine intisap etmediği ve ehl-i sünnet yolunu tuttuğu görülmektedir. Zira Süddî, bu fırkaların arasındaki en büyük intilaf sebebi olan ru'yetullah (Allah'ın görülmesi) ve mürtekibü'l-kebîre (büyük günah işleyenin durumu) hususlarına bahis konusu olan ayetlere yaptığı tefsirlerde, ehl-i sünnet yolunu tuttuğunu açık bir şekilde göstermiştir. Süddî'nin; “Gözler O’nu idrak edemez ama O, gözleri idrak eder. O, en gizli şeyleri bilendir, (her şeyden) hakkıyla haberdar olandır." 59 ayetinin tefsirine dair "Hiçbir şey onu göremez, o ise yaratılmış olanları görür." ${ }^{60}$ ve "Şüphesiz Allah kendisine ortak koşulmasını bağışlamaz. Bunun dışında dilediğini bağışlar." ${ }^{1}$ ayetine dair "Allah büyük günah işlemekten sakınan müslümanları bağışlar." ${ }^{2}$ açıklamaları, onun ehl-i sünnet çizgisinde bulunduğuna dair önemli bir delil olarak kabul edilebilir.

\subsubsection{Lügavî Yönü}

Süddî'den gelen tefsir rivayetlerinin lügavî yönünü ele almadan önce İbn-i Abbas'ın “Eğer Allah'ın kitabından bir kelimenin ne olduğunu anlamazsanız şiire başvurun. Zira şiir Arabın dîvanıdır." ${ }^{3}$ sözünü zikretmek yerinde olacaktır. Süddî'nin, öğrencisi olması ve ondan ders almasına rağmen İbn Abbas'ın bu tavsiyesine uyduğunu söyleyebilmek mümkün değildir. Süddî'nin tefsirine bakıldığında onun sadece bir yerde Hutam b. Hind'e ait üç beyit zik-

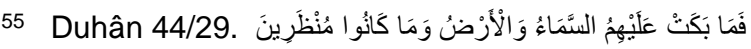

56 Taberî, Câmiu“l-Beyân, XXI, 41.

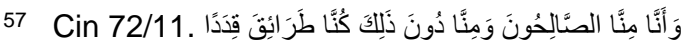

58 Suyûtî, ed-Dürrü'l-Mensûr, XV, 22.

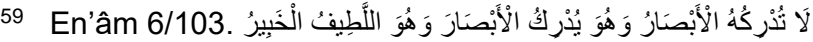

60 Taberî, Câmiu'I-Beyân, IX, 462; İbn Kesîr, Tefsîru'I-Kur'âni'l-Azîm, VI, 128; Suyûtî, ed-Dürrü'l-Mensûr, VI, 163.

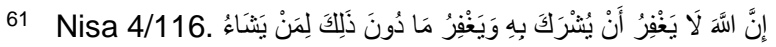

62 Taberî, Câmiu'l-Beyân, VII, 485.

63 Kayrevânî, Ebû Alî Hasen b. Reşîk Ezdî İbn Reşîk, el-'Umde fî Mehâsini’ş-Şi'ri ve Âdâbih, thk. Muhammed Muhyiddîn Abdulhamîd, Dâru'l-Cîl, Beyrut, 1981, I, 30.
} 
rettiğini görürüz. Ancak onun bu beyitleri zikretmesinin amacı, kapalı olan manayı açmak değil nüzul sebebi ile ilgili bir açıklama yapmaktır. ${ }^{64}$

Süddî manası kapalı olan ayetleri açıklarken, şiirle istişhadda bulunmak yerine sözlük anlamlarını vererek kapalılığı gidermeyi daha çok tercih etmiştir ve kendisine isnâd edilen rivayetlerde bu yola başvurduğu yerler oldukça fazladır. Örneğin Süddî, Sâffât suresi 146. ayette geçen 'يقطين' kelimesinin 'قع ' kelimesi ile tefsir etmiş ve Arapların kabak anlamına gelen bu kelimeyi 'دباع' lafzı ile kullandıklarını beyan etmiştir. ${ }^{65}$ Yine Müzzemmil suresi 5. ayette geçen 'نقيل' kelimesi de Süddî tarafından Arapça'da kullanımından da örnek verilerek 'كرئ 'selimesi ile açıklanmıştır. ${ }^{66}$

Süddî'nin yabancı dilden Arapça'ya geçmiş ve Kur'ân'da yer alan kelimeler hakkında bilgiler verdiği de görülmektedir. Bakara suresi 57-58. ayetlerde ${ }^{67}$ Yahudilerin 'hıtta (bizi bağışla)' lafzını 'hınta (buğday)' olarak zikrettikleri ve bunun da İbranca kırmızı buğday anlamına gelen 'hittâ sumhasâ' lafzına olan benzerlikten geldiği Süddî tarafından zikredilmiştir. ${ }^{68}$

\subsubsection{Kur'ân'da Arapça Olmayan Kelimelerin Bulunduğunu Kabul Etmesi}

Âlimler Kur'ân'da Arapça'nın dışındaki dillere ait kelimelerin olup olmadığı hakkında ihtilafa düşmüştür. ${ }^{69}$ Süddî ise, Kur'ân'da; Nabat dilinden, İbranca'dan, Kıptî dilinden, Habeş dilinden, Yemen dilinden ve Süryanice'den bazı kelimeler olduğunu tespit etmiş ve yeri geldikçe bunları açıklamaya çaış̧ıştır. Kur'ân, thk. Abdullah b. Abdulmuhsin et-Türkî, Müessesetü'r-Risâle, Beyrut, 2006 XXI, 324; Şevkânî, Muhammed Ali b. Muhammed, Fethu'l-Kadîr, thk. Abdurrahman Umeyre, Daru'l-Vefâ, Mansûre, 1994, V, 419.

67 "Hani bir zamanlar 'Şu şehre girin de onun nimetlerinden dilediğiniz şekilde bol bol yiyin ve kapıdan secde ederek girin ve 'hıtta (bizi bağışla)' deyin ki, size, hatalarınızı mağfiret ediverelim, iyilik yapanlara nimetlerimizi daha da arttıracağız.' dedik. Bunun üzerine o zulme devam edenler sözü değiştirdiler, onu kendilerine söylenildiğinden başka bir şekle soktular. Biz de kötülük yaptıkları için o zalimlere

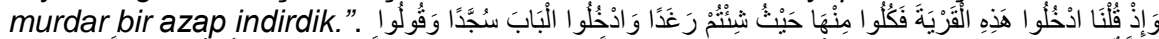

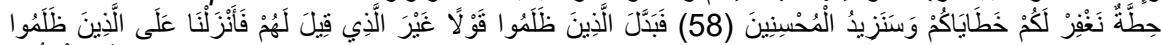

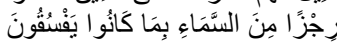

68 Taberî, Câmiu'I-Beyân, I, 725; Kurtubî, el-Câmî‘ li-Ahkâmi'l-Kur'ân, II, 125.

69 
Örneğin Süddî, "Tâ Hâ"70 lafzının Nebâtî dilinde "Ey insan!"71, Kehf suresi 107. ayetteki 'Firdevs' kelimesinin ise aynı dilde cömertlik manasına geldiğini söylemiştir. ${ }^{72}$ Taberî ve İbn Kesîr, Yûsuf suresi 23. ayette yer alan 'هيت لكم لك' ' lafżının Kıptî dilinde Taberî ve Kurtubî, Sebe suresi 14. ayetteki 'منسأة' lafzının Habeş dilinde 'ملر' 'العصا' manasına geldiğini Süddî'den rivayet etmişlerdir. ${ }^{74}$

\subsection{Yöntemi}

Tabiîn müfessirleri, Kur'ân'ı anlamak için öncelikle Kur'ân'ın kendisine, sahabenin, Hz. Peygamber'den nakillerine, sahabeden gelen tefsirle ilgili rivayetlere; sonra da Ehl-i Kitap'tan aldıkları bazı bilgilere, kendi ictihad ve görüşlerine dayanırlardı. ${ }^{75}$ Süddî, yukarıda saydığımız kaynakları kendine çıkış noktası olarak almakla beraber bunlara ilaveten re'y ve ictihad yöntemini kullanarak tefsirinde yer yer şer'î hükümler vermiş, Arapça olmayan kelimelere dair açıklamalarda bulunmuş, belagat ve edebiyat konularına değinmiş ve tefsire ait farklı bilgilerden de faydalanmıştır.

Şimdi Süddî’nin tefsirinde kullandığı bu kaynakları kısaca açıklamaya çalışalım:

\subsubsection{Kur'ân'ın Kur'ân ile Tefsiri}

Kur'ân tefsirinin ilk kaynağı elbette ki Kur'ân'ın kendisidir. Süddî'den gelen tefsir rivayetlerinde de onun, Kur'ân tefsirinin ilk adımı sayılabilecek bu yöntemden uzak kalmadığı görülmektedir. Örneğin "Onlar tartışıllarken, en yüksek topluluk (mele-i a'lâ) hakkında benim hiçbir bilgim yoktu" 76 ayetini "Rabbin meleklere: 'Ben yeryüzünde bir halife yaratacağım.' dediği vakit onlar: 'Oradaki nizamı bozacak ve yeryüzünü kana bulayacak bir mahlûk mu yarata-

70 Tâ Hâ 20/1. طه

71 Kurtubî, el-Câmî‘ li-Ahkâmi'l-Kur'ân, XIV, 9; İbn Kesîr, Tefsîru'l-Kur'âni'l-Azîm, V, 271, Şevkânî, Fethu'l-Kadîr, III, 489.

72 Suyûtî, ed-Dürrü'l-Mensûr, IX, 694; Âlûsî, Şihabuddin Mahmud, Rûhu'l-Me'ânî fî Tefsîri'-Kur'ani'l-Azîm ve's-Seb'i'l-Mesânî, Dâru İhyâi't-Turâsi'l-Arabî, Beyrut, t.y., $\mathrm{XVI}, 50$.

73 Taberî, Câmiu'I-Beyân, XIII, 72; İbn Kesîr, Tefsîru'I-Kur'âni'l-Azîm, IV, 379.

74 Taberî, Câmiu'I-Beyân, XIX, 238; Kurtubî, el-Câmî' li-Ahkâmi'l-Kur'ân, XVII, 270.

75 Demirci, Muhsin, Tefsir Tarihi, Marmara Üniversitesi İlahiyat Fakültesi Vakfı Yayınları, İstanbul, 2003, s. 94; Duman, M. Zeki, "Tabiûn Döneminde Tefsir Faaliyeti (Meşhur Müfessirler, Kaynakları ve Bu Tefsirin Değeri)", Erciyes Üniversitesi Illahiyat Fakültesi Dergisi, sayı: 4, 1987, s. 231-232; Turgay, Nurettin, "Tabiunun/ Tabiilerin Tefsir İlmindeki Yeri”, Bilimname, 2010/1, cilt: VIII, sayı: 18, s. 102-106.

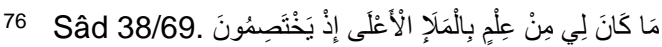


caksın? Oysa biz seni överek tesbih ve takdis etmekteyiz.' dediler. Allah: 'Ben, sizin bilmediğiniz pek çok şey bilirim.' buyurdu."77 ayeti ile açıklamıştır. ${ }^{78}$

Yine Süddî, "Orada Zekeriya Rabbine dua etti..."79 ayetindeki Zekeriyya'nın duasını; “...Rabbim! Beni tek başıma bırakma, sen varislerin en hayırlısısın." ${ }^{80}$ ayeti ile tefsir etmiştir. ${ }^{81}$

\subsubsection{Kur'ân'ın Sünnet ile Tefsiri}

Tefsirde başvurulması gereken ikinci kaynak olan hadîs-i şeriflerden Süddî de yararlanmış ve Hz. Peygamber'e nisbet edilen otuz kadar hadisi tefsirinde zikretmiştir. Süddî'nin naklettiği bu hadisler sebeb-i nüzûl, fıkhî hükümler, sahabeler hakkındaki menkıbeler ve bazı gazvelere dairdir.

Süddî “Ey iman edenler! Allah'a itaat edin. Peygamber'e itaat edin ve sizden olan ulu'l-emre (idarecilere) de. Herhangi bir hususta anlaşmazlığa düştüğünüz takdirde, Allah'a ve ahiret gününe gerçekten inanıyorsanız, onu Allah ve Resûlüne arz edin. Bu, daha iyidir, sonuç bakımından da daha güzeldir."82 ayetinin nüzûl sebebini açıklarken Hz. Peygamber'den gelen bir nakilden faydalanmıştır. Buna göre bu ayet, Hâlid b. Velîd komutanlığında savaşa giden bir birlikte yer alan Ammâr b. Yâsir'in müslüman olmak isteyen bir düşman askerine komutanından izinsiz eman vermesi, bu sebeple komutanıyla arasında tartışma çıkması, sefer dönüşü Hâlid ile Ammâr'ın Hz. Peygamber'in huzurunda tartışması, Hz. Peygamber'in Ammâr'ın verdiği teminatı tanıdığı ancak komutanından izinsiz bir daha böyle bir iş yapmaması gerektiğini söylemesi üzerine inmiştir. Süddî bu olayı naklettikten sonra Hz. Peygamber'in "Ammâr'a söven Allah'a sövmüş olur, Ammâr'a buğzeden Allah'a buğzetmiş olur, Ammâr'a lanet eden Allah'a lanet etmiş olur." 83 hadisini aktarmıştır. ${ }^{84}$

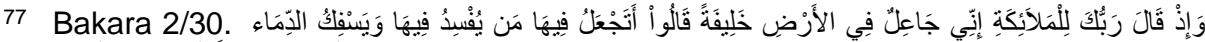

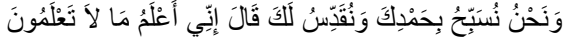

78 Taberî, Câmiu'I-Beyân, XX, 142; Kurtubî, el-Câmî‘ li-Ahkâmi'l-Kur'ân, XVIII, 236.

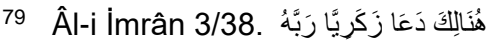

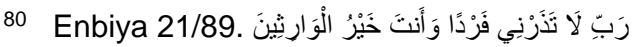

81 Taberî, Câmiu'I-Beyân, V, 360.

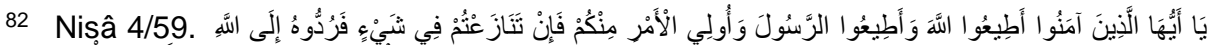

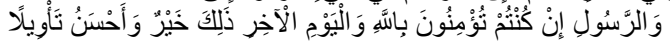

83 Taberânî, Ebu'l-Kâsım Süleyman b. Ahmed b. Eyyûb el-Lahmî, Mu'cemu'l-Kebîr, thk. Hamdi b. Abdulmecîd es-Selefî, Mektebetü İbn Teymiyye, Kahire, 1994, Hadis No: 3830, IV, 112; Hindî, Alâüddîn Alî b. Müttakî b. Hüsâmüddîn el-Bürhanfûrî, Kenzü'l-'Ummâl fî Süneni'l-Akvâl ve'l-Ef'âl, thk. Bekrî Hayyânî, Safvet es-Sekâ, Müessesetü'r-Risâle, Beyrut, 1981, Hadis No: 37389, 37391, XIII, 533-534.

84 Taberî, Câmiu'I-Beyân, VII, 178; Suyûtî, ed-Dürrü'I-Mensûr IV, 503. 
"Hani sen sabah erkenden müminleri savaş mevzilerine yerleştirmek için ailenden ayrılmıştın. Allah, hakkıyla işiten ve bilendir." 85 ayetine dair Süddî'den gelen rivayet şöyledir: Müşriklerin Uhud Dağı'nın eteklerinde toplandığını haber alan Hz. Peygamber'e; özellikle Bedir savaşına katılmayan bazı sahâbîler, Medine'den çıkıp düşmana hücum etmeyi teklif ettiler. Bunun üzerine $\mathrm{Hz}$. Peygamber zırhını kuşanmıştır. Düşmana hücum edilmesini teklif edenlerden bazıları, Hz. Peygamber'i böyle görünce bu ısrarlı tekliflerinden pişman olarak “Acaba biz, Resûlullah'ı zorladık mı? Ey Allah'ın Resûlü, dilersen Medine'de kalalım.” deyince Hz. Peygamber şu cevabı vermiştir: "Bir Peygamber zırhını giydikten sonra Allah, onun karar verdiği hususta hükmünü verinceye kadar geri dönmesi ona yakışmaz." ${ }^{86}$ buyurmuşlardır. ${ }^{87}$

\subsubsection{Tarihî Bilgilerden Yararlanması}

Tefsirde, tarihî bilgilerden yararlanma konusuna gelince, Süddî bu alanın önde gelenlerinden biri olarak kabul edilebilir. Zira o tefsirinde; İsrailoğulları ${ }^{88}, \mathrm{~Hz}$. Musa ${ }^{89}$, firavun ${ }^{90}, \mathrm{~Hz}$. İbrahim ${ }^{91}, \mathrm{~Hz}$. Yusuf ve kardeşleri92, Hz. İsa ve havarileri93, Lût kavmi94, Âd kavmi ${ }^{95}$, Semûd kavmi96 ve buna benzer konularda tarihî bilgilere oldukça yoğun bir şekilde yer vermiştir. Süddî bunun gibi İslam öncesi tarihî olaylara ilişkin bilgiler vermenin yanı sıra gazveler ve

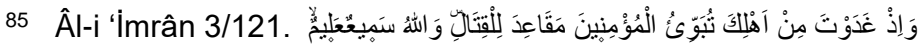

86 Nesâî, Ebû Abdurrahman Ahmed b. Ali b. Şuayb, Sünenül-Kübrâ, thk. Hasan Abdulmun'in Şelebi, Müessesetü'r-Risâle, Beyrut, 2001, Kitâbu't-Ta'bîr, 17.

87 Taberî, Câmiu'I-Beyân, VI, 9. Benzer örnekler için bkz. Taberî, VII, 178; XI, 317.

88 Taberî, Câmiu'I-Beyân, IV, 441, V, 578, VIII, 237, IX, 121, XVI, 140; Kurtubî, elCâmî' li-Ahkâmi'l-Kur'ân, IV, 228-229, V, 203; Suyûtî, ed-Dürrül'-Mensûr, V, 593.

89 Taberî, Câmiu'I-Beyân, I, 670, II, 78-79, X, 468; İbn Kesîr, Tefsîru'l-Kur'âni'l-Azîm, III, 479-480.

90 Taberî, Câmiu'I-Beyân, I, 648, X, 387, XVI, 61, Suyûtî, ed-Dürrü'l-Mensûr, XI, $242-$ 243; Âlûsî, Rûhu'I-Me'ânî, XIX, 65.

91 Taberî, Câmiu'I-Beyân, II, 518, IV, 627, XVI, 295, XVI, 306; İbn Kesîr, Tefsîru'lKur'âni'I-Azîm, II, 455, IX, 412-413; Kurtubî, el-Câmî‘ li-Ahkâmi'l-Kur'ân, II, 124125; Âlûsî, Rûhu'I-Me'ânî, I, 381.

92 Taberî, CâmiułI-Beyân, XIII, 29, XIII, 34, XIII, 80, XIII, 152, XIII, 223, XIII, 277, XIII, 369; İbn Kesîr, Tefsîru'l-Kur'âni'l-Azîm, IV, 375, IV, 387, IV, 414; Kurtubî, el-Câmî̀ li-Ahkâmi'l-Kur'ân, XI, 280.

93 Taberî, Câmiu'I-Beyân, V, 437, V, 446, V, 447, VII, 654, IX, 121; Kurtubî, el-Câmî̀ li-Ahkâmi'l-Kur'ân, VII, 212; Şevkânî, Fethu'l-Kadîr, I, 571.

94 Taberî, Câmiu'I-Beyân, XII, 496, XII, 515, XII, 519; Suyûtî, ed-Dürrü'l-Mensûr, VIII, 108, VIII, 109.

95 Taberî, Câmiu'I-Beyân, X, 278.

96 Taberî, Câmiu“l-Beyân, X, 284. 
seriyyeler gibi İslam sonrası bazı tarihî vakalar hakkında da rivayetlerde bulunmuştur. ${ }^{97}$

Misal olarak kardeşlerinin Hz. Yûsuf'u kuyuya atması ile ilgili olarak Süddî'den nakledilen bir rivayet şu şekildedir: Kardeşleri Hz. Yûsuf'u kuyuya sarkıtmaya başladıklarında, o kuyunun kenarına tutunarak direnmiş; bunun üzerine kardeşleri onun ellerini bağlayarak üzerinden gömleğini çıkarmışlardır. Hz. Yûsuf bunun üzerine: "Ey kardeşlerim! Gömleğimi bana geri veriniz. Bu kuyuda ona sarılayım. Ölürsem kefenim olur, hayatta kalırsam onunla avret mahallimi örterim." dedi. Kardeşleri ona: "Güneşi, ayı ve on bir yıldızı çağır da onlar seni teselli etsinler ve seni giydirsinler." diyerek cevap verince o bu sefer: "Ben hiçbir şey görmedim." demiştir. Ancak kardeşleri onu kuyuya sarkıtmış, kuyunun ortasına ulaştığı sırada de düşüp ölsün diye onu bırakıvermişlerdir. Hz. Yûsuf kuyuda bulunan suyun üzerine düşmüş, sonra da bir kaya parçasına ulaşıp üzerine çıkmıştır. ${ }^{98}$

“Mûsâ, kavmine dedi ki: ‘Ey kavmim! Sizler, buzağıyı ilâh edinmekle kendinize yazık ettiniz. Gelin yaratıcınıza tövbe edin de nefislerinizi öldürün (kendinizi düzeltin). Bu, Yaratıcınız katında sizin için daha iyidir. Böylece Allah da onların tövbesini kabul etti. Çünkü $O$, tövbeleri çok kabul edendir, çok merhametlidir." 99 Süddî bu ayette geçen 'nefislerinizi öldürün' lafzı hakkında, buzağıya tapanlarla tapmayanların kılıç kılıca karşı karşıya geldiklerini, çarpışma esnasında iki tarafın da helâk olacak kadar fazla sayıda can kaybı yaşadığını rivayet etmiştir. Hatta aralarından yetmiş bin kişi ölmüş ve nihayet $\mathrm{Hz}$. Mûsâ ve Hârûn "Rabbimiz, İsrâiloğulları helâk oldu, Rabbimiz, arta kalanlar(ı bağışla)!" diye dua ettiler. Bunun üzerine Allah onlara silahlarını bırakmalarını emretti ve tövbelerini kabul etti. Her iki gruptan da öldürülenler şehîd oluyordu. Kalanların da günahları bağışlanmış oluyordu. İşte Allah'ın, "Allah da tövbenizi kabul etmişti. Çünkü O, tövbeleri çok kabul edendir, çok merhametlidir." sözünün anlamı budur. ${ }^{100}$

Hendek savaşından bahseden, "Hani onlardan bir grup, "Ey Medine halkı! Sizin burada durmak imkânınız yok. Haydi, geri dönün.” demişti. Onlardan bir başka grup da, "Evlerimiz korumasız." diyerek Peygamberden izin istiyorlardı. Oysa evleri açık korumasız değildi. Onlar sadece kaçmak istiyor-

97 Taberî, Câmiu'I-Beyân, VI, 9, VI, 13, VI, 217, XI, 65; İbn Kesîr, Tefsîru'l-Kur'âni'lAzîm, IV, 23, Suyûtî, ed-Dürrü'l-Mensûr, XI, 750, Kurtubî, el-Câmî‘ li-Ahkâmi'lKur'ân, XVII, 99.

98 Taberî, Câmiu'I-Beyân, XIII, 29; Kurtubî, el-Câmî‘ li-Ahkâmi'l-Kur'ân, XI, 278.

99 Bakara 2/54. وََ

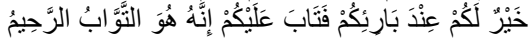

100 İbn Kesîr, Tefsîru'l-Kur'âni'l-Azîm, I, 262-263. 
lardı."101 ayetinde asılsız bahaneler ileri sürerek Hz. Peygamber'den izin isteyen kimselerin Benî Hârise'den ensâra mensup iki kişi olduğu Süddî tarafından rivayet edilmiştir ki bunlar, Ebu Arâbe b. Evs ve Evs b. Kayzî'dir. ${ }^{102}$

\subsection{4. Şer'î Hükümler Çıkarması}

Süddî re'y ve ictihada dayanarak tefsirinde bazı şer'î hükümler de istinbat etmiştir. Onun en çok üzerinde yoğunlaştığı konular ise namaz, hac, zekât, talak, evlilik, miras ve taharet gibi konulardır. Süddî tefsirinde bu konularla ilgili fıkhî hükümleri verirken ayet ve hadisleri delil gösterdiği gibi bunlar ile istişhad etmeden kendi ictihadıyla hükümler verdiği de olmuştur. Süddî tefsirinin muhtelif yerlerinde yirmi beşten fazla furu'u fıkı konusunda değerlendirmeler yapmıştır. ${ }^{103}$

Örneğin, "Kendileri, geriye zayıf çocuklar bıraktıkları takdirde onların durumundan endişe edecek olanlar, (yetimlerin hakkına dokunmaktan da) çekinsinler. Allah'tan korksunlar ve doğru söz söylesinler."104 ayeti hakkında Süddî, ölümü anında malını vasiyet eden kişinin yanında bulunan kimselerin, vasiyet edenin malını dağıtması için onu teşvik etmemesi ve geriye kalan mirasçılarını mağdur etmemesi gerektiğini; ona malından, mirasçılarını mağdur etmeyecek kadarını vasiyet etmesini tavsiye etmelerini söylemiştir. Zira kendileri vasiyet eden kişinin durumunda olsalardı geride bırakacakları çocuklarının mağdur edilmelerine razı olmazlardı. Öyleyse kendi çocukları için endişelendikleri gibi müslüman kardeşlerinin çocukları için de endişelenmeleri ve onlara doğru sözle doğru tavsiyelerde bulunmaları gerekir. ${ }^{105}$

"Eğer bir kadın kocasının, kendisine kötü davranmasından yahut yüz çevirmesinden endişe ederse, uzlaşarak aralarını düzeltmelerinde ikisine de bir günah yoktur. Uzlaşmak daha hayırıdır."106 ayetini Süddî, bir kadının eşinde kendisinin yaşlanmasından yahut çocuk sahibi olamamasından ötürü bir soğukluk görmesi ve eşinin de ona "Ben senden daha genç ve belki de bana bir çocuk verecek biri ile evlenmek istiyorum." demesi durumunda kadının gününden vaz geçerek ve nafakasının bir kısmından fedakarlık ederek anlaşabileceği ve boşanmadan kocasının yanında kalabileceği şeklinde açıklamıştır. Süddî bu ayetin Hz. Peygamber ve eşi Sevde bint Zem‘a hakkında nâzil olduğunu belirterek görüşünü desteklemiştir. Buna göre Sevde yaşlanınca Hz.

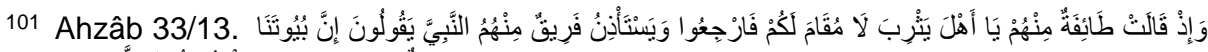

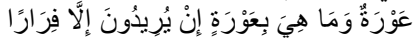

102 Kurtubî, el-Câmî' li-Ahkâmi'l-Kur'ân, XVII, 99.

103 Kurtubî, el-Câmî‘ li-Ahkâmi'l-Kur'ân, VI, 129, VI, 143, VII, 25, VII, 270, VII, 325-326.

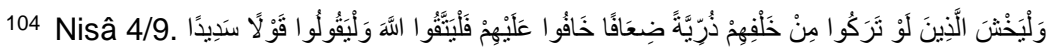

105 Taberî, Câmiưl-Beyân, VI, 448.

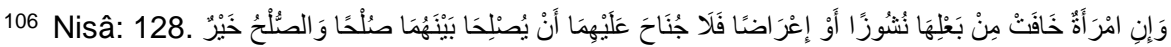


Peygamber başka bir eş almak istemiş, Sevde ise kendi gününü Hz. Aişe'ye vermiş ancak Hz. Peygamber'in kendisini boşamamasını istemiştir. ${ }^{107}$

\subsubsection{Sebeb-i Nüzûl Rivayetlerini Kullanması}

Hz. Peygamber'e sorulan bir soru yahut vuku bulan bir hadise dolayısıyla birkaç ayetin ya da bütün bir surenin indirilmesine âmil olan olay, gelişme veya şartlara 'sebeb-i nüzûl' denilmektedir. ${ }^{108}$ Bir ayetin nüzûl sebebini bilmek, o ayetin manasının anlaşılmasına yardımcı olur. Zira sebebi bilmek, müsebbibi bilmeye götürdüğü gibi ${ }^{109}$ nüzûl sebebini beyan etmeden ve üzerine inmiş olduğu olayı bilmeden bir ayetin tefsirinin mümkün olmayacağı âlimler tarafından ifade edilmiştir. ${ }^{110}$ Mevzubahis soru, olay yahut şartların bilinmesinin yegâne yolu tarihi bilgiler ve sahabîlerden nakledilen rivayetler olduğu için nüzûl sebeplerinin makbuliyeti, âlimler tarafından ilgili rivayetlerin sıhhatine bağlanmış, dolayısıyla hadis usûlünde hadislerin sıhhati için aranan şartlar nüzûl sebebi rivayetleri için de geçerli sayılmıştır. ${ }^{111}$

Süddî de tefsirinde, nüzûl sebeplerine ayrı bir ihtimam göstermiş ve yüzden fazla nüzûl sebebi zikretmiştir. Nüzûl sebeplerini bildirirken bazen "Rasûlüllah'a şöyle soruldu ve bunun üzerine şu ayet indi." şeklinde bir ifade kullanmış, bazen de ayetin inmesine neden olan hadiseyi zikretmiştir. Süddî'nin bu nüzûl sebeplerini naklederken hem hakiki iniş sebepleri olarak kabul edilen ve delil kabul edilen kalıpları hem de delil kabul edilmeyen, sadece intimal bildiren sebeb-i nüzûl rivayet etme kalıplarını ${ }^{112}$ da kullanmıştır. Süddî'nin bu nüzûl sebebi zikretme ifadelerinden birinci türe şu ayet örnek olarak gösterilebilir: "(Çocuklar sadece) ikiden fazla kız iseler, (ölenin geriye) bıraktığının üçte ikisi onlarındır. Eğer kız bir ise (mirasın) yarısı onundur."113 Taberî bu ayetin nüzûl sebebi hakkında; Süddî'ye isnâd ettiği bir rivayeti şöyle nakletmektedir: "Cahiliye dönemi insanları, cariyelere ve küçük köle çocuklara mirastan pay vermiyorlardı. Mirastan ancak, savaşa katılabilen erkekler pay alabiliyorlardı. Hassan b. Sabit'in kardeşi Abdurrahman öldü ve arkasında

107 Taberî, Câmiu'l-Beyân, VII, 563.

108 Cerrahoğlu, Tefsir Usûlü, s. 115; Albayrak, Halis, Tefsir Usûlü, Şule Yayınları, İstanbul, 1998, s. 159.

109 İbn Teymiyye, Mukaddime fî Usûli't-Tefsir, s. 16.

110 Vâhidî, Ebu'l-Hasan Ali b. Ahmed b. Muhammed en-Nisâbûrî, Esbâbü'n-Nüzûl, thk. Kemâl Besyûnî Zağlûl, Dâru'l-Kütübi'l-IImiyye, Beyrut, 1991, s. 10.

111 Demirci, Muhsin, Tefsir Usûlü, Marmara Üniversitesi İlahiyat Fakültesi Vakfı Yayınları, 3. bs, İstanbul, 2003s. 151.

112 Nüzûl sebebi rivayet etme kalıpları ve bunların delil kabul edilme kriterleri için bkz. Zürkânî, Muhammed Abdülazîm, Menâhilü'l-İrfân fî 'Ulûmi'l-Kur'ân, thk. Fevvâz Ahmed Zemerlî, Dâru'l-Kitâbi'l-Arabî, Beyrut, 1995, I, 96.

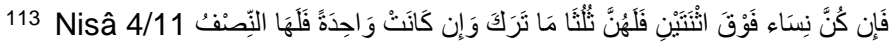


karısı Ümmü Kücce'yi ve beş çocuğunu bıraktı. Varisler geldiler ve bütün mirası aldılar. Ümmü Kücce Rasûlüllah'a gitti ve şikâyette bulundu. Bunun üzerine Allah, bu ayeti nâzil etti."114

"Hani münafıklar ve kalplerinde hastalık olanlar, 'Allah ve Resûlü bize ancak aldatmak için vaadde bulunmuşlar.' diyorlardı." ayetinin ${ }^{115}$ nüzûl sebebi Süddî tarafından Hz. Peygamber'e dayandırılarak rivayet edilmiştir. Hendek savaşı öncesinde hendek kazılırken Hz. Peygamber kazmasını taşa vurmuş ve gökyüzündeki yıldııımlar gibi parlak ve güçlü bir kıvılcım çıkmış, ikinci sefer vurduğunda da aynısı tekrarlanmıştır. Bunu gören Selmân, "Ey Allah'ın Rasûlü! Kazmayı her vuruşunda gökyüzüne yükselen kıvılcımlar gördüm." deyince Hz. Peygamber, "Sizin için Rum saraylarının, Yemen şehirlerinin kapıları açılmıştır." diyerek fetih müjdesi vermiştir. Bu olay insanlar arasında yayılınca ensardan Beşîr b. Muattib "Muhammed bize Yemen'in şehirlerini, Rum saraylarını vaad ediyor ama biz ölüm korkusuyla intiyacımızı gidermeye bile gidemiyoruz. Yemin olsun bu bir aldatmadır." demiş ve bunun üzerine Allah bu ayeti nâzil etmiştir. ${ }^{116}$

Süddî'nin her hangi bir açıklama yapmadan ve Hz. Peygamber ile ilgili bir nakilde bulunmadan, doğrudan nuzûle sebep olan olayı anlatmasının örneği ise "'Allah fakirdir biz ise zenginiz.' diyenlerin sözlerini Allah elbette işitmiştir."117 ayetinin nüzûl sebebine dair Taberî'nin Süddî'den naklettiği şu rivayette görülmektedir: "Mersedoğullarından bir Yahudi olan Finhas ismindeki biri Ebû Bekir ile karşılaştı ve konuştular. Ebû Bekir ona 'Ya Finhas! Allah'tan kork, O'na iman et, doğru kimselerden ol ve Allah'a güzel bir borç ver.' dedi. Finhas şöyle karşılık verdi: 'Ya Ebû Bekir! Hem Rabbimiz zengindir diyorsun hem de bizim malımızdan borç istiyorsun. Sadece fakirler zenginlerden borç ister. Şayet sen söylediğinde doğru isen sizin Allah'ınız fakirdir.' dedi. Bunun üzerine Allah bu ayeti indirdi."118

"Rableri onlara, kendi katından bir rahmet, bir hoşnutluk ve kendilerine içinde tükenmez nimetler bulunan cennetler müjdelemektedir." mealindeki Tevbe suresi 21. ayete dair Süddî'den nakledilen nüzûl sebebi rivayeti de bu türe örnek gösterilebilir. Rivayete göre Hz. Ali, İbn Abbas ve Şeybe b. Osman birbirlerine karşı övünüyorlardı. İbn Abbas hacılara su verdiği için, Şeybe de Kabe'yi imar ettiği için diğerlerinden faziletli olduklarını söylüyorlardı. Hz. Ali

\footnotetext{
114 Taberî, Câmiu'l-Beyân, VI, 457.

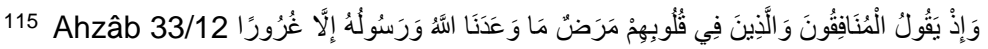

116 Suyûtî, ed-Dürrül'-Mensûr, XI, 750-751.

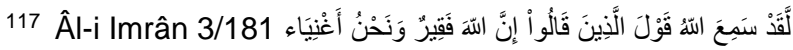

118 Taberî, Câmiu'l-Beyân, VI, 279.
} 
ise onlara "Ben Rasûlullah ile birlikte hicret ettim ve onunla beraber Allah yolunda cihad ettim." diyerek karşılık verdi ve Allah bu ayeti indirdi. ${ }^{119}$

\subsubsection{Kırâatler}

Kırâat ilmi; "Kur'ân kelimelerinin nasıl okunacağını ve râvilerine nisbet etmek suretiyle bu kelimeler üzerindeki farklı okuyuşları konu edinen bir ilim" olarak tarif edilmiştir. ${ }^{120} \mathrm{~Hz}$. Peygamber hayatta iken, Kur'ân'ın farklı şekillerde okunmasına bizzat kendisinin müsaade ettiğini kaynaklarda belirtilmektedir. Özellikle yedi harf olgusuyla bağlantılı olarak Hz. Ömer ve Hişam b. Hakîm arasında cereyan eden olaya baktığımızda ${ }^{121}$, Kur'ân'ın okunması konusunda Hz. Peygamber'in kolaylık tarafını seçtiğini, ashabını külfete sokmak istemediği görülmektedir. ${ }^{122}$ İşte bu şekilde, henüz Hz. Peygamber zamanında ortaya çıkan Kur'ân'ın farklı okunuşları, sahabe ve tabiîn kanalıyla günümüze kadar ulaşmıştır.

Kıraâtlar genellikle 'Yedi kıraât' veya 'On kıraât' şeklinde anılmaktadırlar. Sahîh ve meşhur bu on kırâatin imamları Süddî ile hemen hemen çağdaş olsalar da kıraâtlar için yapılmış bu sınıflama Süddî'nin yaşadığı devirden sonra meydana geldiği için onun yaptığı kırâat tercihlerinin mezkûr sınıflamaya dâhil edilmesi doğru olmayacaktır. Süddî'nin kıraatlere dair yaptığı bazı nakillere örnek olarak şu ayetleri gösterebiliriz:

Kurtubî; Ömer b. Abdülaziz, İbn-i Kesîr, Katâde ve Süddî'nin ' وََرَرْنَ

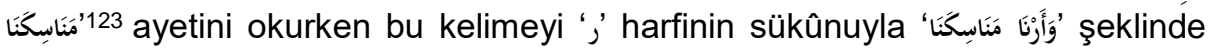
okuduklarını nakletmiştir. ${ }^{124}$ Bu kıraât, İbn Kesîr'in tercih ettiği kırâattır. ${ }^{125}$

119 Taberî, Câmiu'I-Beyân, XI, 380.

120 İbnü'l-Cezerî, Şemseddin Ebu'l-Hayr Muhammed b. Muhammed, Müncidü'lMukri'în ve Mürşidü't-Tâlibîn, Dâru'l-Kütübi'l-IIlmiyye, Beyrut, 1999, s. 9.

121 Rivayet edildiğine göre Hz. Ömer, Hişam'ın, Furkan Suresini, onun Hz. Peygamber'den öğrendiğinden farklı bir şekilde okuduğunu işitir. Sonra onu $\mathrm{Hz}$. Peygamberin huzuruna getirir ve şikâyetini bildirir. Hz. Peygamber Furkan Suresini önce Hişam'a okutur ve "Böyle indirildi." der. Sonra Hz. Ömer'e okutur ve okumasını bitirdikten sonra ona da "Böyle indirildi." der. Sonra da "Kur'ân yedi harf üzere indirilmiştir, hangisi kolayınıza gelirse onu okuyun" buyurmuştur. [Ahmed b. Hanbel, Müsned, I, 40, 43, 264; el-Buhârî, Sahîh, VI, 227-228; Müslim, Sahîh, I, 56; en-Nesâî, Sünen, II, 116.]

122 Albayrak, Tefsir Usûlü s. 30.

123 Bakara 2/128.

124 Kurtubî, el-Câmî'li-Ahkâmi'l-Kur'ân, II, 398.

125 İbn Mücâhid, Ebû Bekr Ahmed b. Musa b. Abbas et-Temîmî, Kitâbu’s-Seb‘a fi'lKırâât, Dâru'l-Maârif, Kahire, 1972, s. 170. 
Kurtubî, Yûnus suresi 30. ayette bulunan 'تبلو' kelimesini Süddî'nin 'تتلو' şeklinde okuduğunu rivayet etmiştir ${ }^{126}$ ki bu kırâat Hamza ve Kisâî'nin tercih ettiği kırâatır. ${ }^{127}$

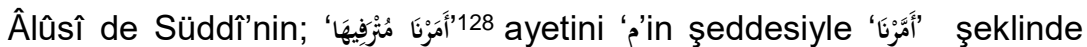
okuduğunu bildirmiştir. ${ }^{129}$ Süddî’nin tercih ettiği bu kırâat, Ebû Amr'ın kırâatidir. ${ }^{130}$

Şevkânî ise Müddessir suresi 5. ayetteki 'الرجز' lafzının Süddî tarafından 'j' harfinin dammıyla okunduğunu haber vermiştir ${ }^{131}$ ki bu da Asım ve Hafs'ın kırâatidir. ${ }^{132}$

\subsubsection{Nâsih-Mensûh}

Nesih sözlükte, 'ortadan kaldırmak, ilgâ etmek, yok etmek, yazmak, bir şeyi bir yerden başka bir yere aktarmak'; terim olarak ise 'şer'î bir hükmü, bir başka şer'î delille kaldırmak veya mukaddem tarihli bir nassın hükmünü, muahhar tarihli bir nass ile değiştirmektir. ${ }^{133}$ Kur'ân'da neshin varlığı tartışmasının tam olarak ne zaman başladığı tespit edilememekle beraber, hicri birinci yüzyılın sonlarına doğru zuhur ettiği söylenebilir. Kur'ân'da neshin bizatihi bulunduğunu söyleyenler, İslam âlimlerinin çoğunluğunu teşkil etmektedir. Bununla beraber her asırda, neshin varlığına dair kanıtları çürütmeye çalışarak antitez hazırlayan âlimler de çıkagelmiştir. ${ }^{134}$

Kur'ân'da neshin varlığını kabul edenlerin bu görüşlerine delil olarak getirdikleri ayetlere dair Süddî'den nakledilen rivayetler, onun Kur'ân'da neshin mevcudiyetini kabul ettiğini göstermektedir. Mesela o, "Herhangi bir ayetin hükmünü yürürlükten kaldırır (nesheder) veya unutturursak, onun yerine daha hayırlısını veya onun benzerini getiririz." 135 ayetini tefsir ederken "Buradaki 'nesh', (hükmü) almak; 'unutturmak', (bu alınan hükmün) terk edilmesi; 'daha hayırlısını getirmek', nesh edilen hükümden daha hayırlı bir hüküm getirmek;

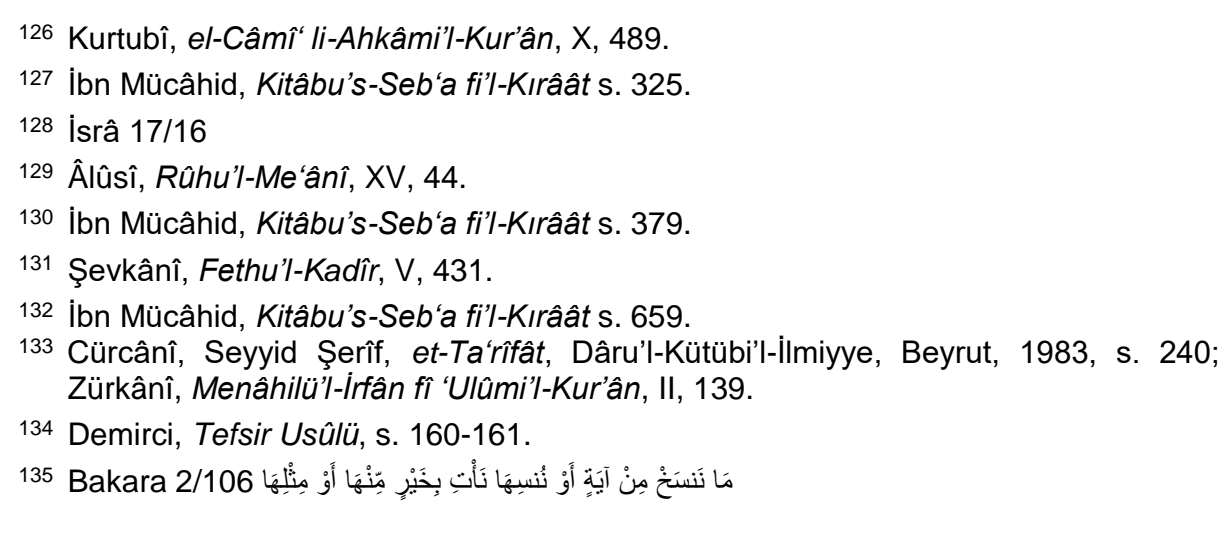


'benzerini getirmek' ise, terk edilen hükmün benzerinin getirilmesi anlamına gelir" demiştir. ${ }^{136}$

"Biz bir âyetin yerine başka bir âyeti getirdiğimiz zaman..." ${ }^{137}$ ayetini tefsir ederken de Süddî, "Buradaki bir ayetin yerine başka bir ayet getirmeden maksat nâsih ve mensûhtur. Yani bu, 'Biz bir ayeti nesh ettiğimiz zaman onun yerine başkasını getiririz.' anlamındadır. İnkârcılar Hz. Peygamber'e 'Sen söylediğin bir şeyi sonradan değiştiriyorsun, bu söylediklerini uyduruyorsun' diyorlardı. Hâlbuki 'Allah ne indirdiğini çok iyi bilmektedir."' demiştir. ${ }^{138}$

Süddî'nin yukarıdaki ayetler için yaptığı açıklamaları göz önüne aldığımızda onun, Kur'ân'da neshin varlığı konusunda, neshe cevaz veren çoğunluğun görüşüne daha yakın olduğu görülmektedir. Bununla birlikte bazı âlimler tarafından inkârcılarla iyi geçinmeyi, onlardan yüz çevirmeyi ve onlardan gelecek eziyetlere sabretmeyi emreden yüzden fazla ayeti nesh ettiği kabul edilen ${ }^{139}$ ve kıâl/seyf ayeti olarak anılan Tevbe suresi 5 . ayet ${ }^{140}$ hakkında Süddî'den nakledilen rivayet dikkat çekicidir. Zira kendisinden nakledilen rivayetlerden neshi kabul ettiği anlaşılan Süddî, mezkûr ayetin Muhammed suresi 4. ayet $^{141}$ ile nesh edildiği görüşündedir. ${ }^{142}$

136 Taberî, Câmiu'I-Beyân, II, 389, 400; İbn Kesîr, Tefsîru'l-Kur'âni'l-Azîm, I, 375, 376, 378.

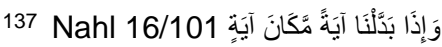

138 Suyûtî, ed-Dürrü'l-Mensûr, IX, 115.

139 İbn Hazm, Ebû Muhammed b. Ali b. Ahmed b. Saîd ez-Zahiri, en-Nâsih ve'lMensûh fi'l-Kur'âni'l-Kerîm, thk. Abdulgaffâr Süleyman Bündârî, Dârü'l-Kütübi'lİlmiyye, Beyrut, 1986, s. 18; Sehavî, Ebu'l-Hasan Alemuddîn Ali b. Muhammed b. Abdüssamed, Cemâlü'l-Kurrâ ve Kemâlu'IIkrâ', Müessesetü'l-Kütübi's-Sekâfiyye, Beyrut, 1999, s. 705, İbn Cüzeyy, Ebu'l-Kâsım Muhammed b. Ahmed b. Muhammed el-Kelbî el-Gırnatî, et-Teshîl li 'Ulûmi't-Tenzîl, thk. Rıza Ferec elHümâmî, Mektebetü'l-Asriyye, Beyrut, 2005, 30-32.

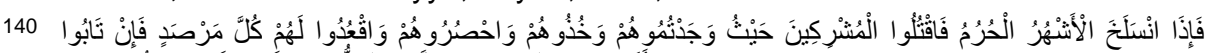

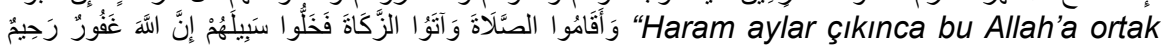
koşanları artık bulduğunuz yerde öldürün, onları yakalayıp hapsedin ve her gözetleme yerine oturup onları gözetleyin. Eğer tövbe ederler, namazı kılıp zekâtı da verirlerse, kendilerini serbest bırakın. Şüphesiz Allah çok bağışlayıcıdır, çok merhamet edicidir."

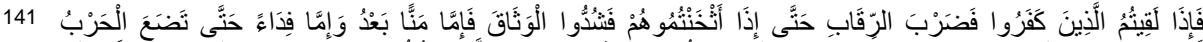

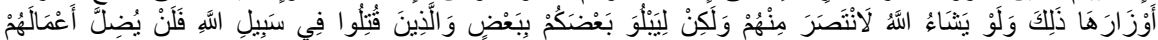
"(Savaşta) inkâr edenlerle karşılaştığınız zaman boyunlarını vurun. Nihayet onları çökertip etkisiz hâle getirdiğinizde bağı sıkı bağlayın (sağ kalanlarını esir alın). Artık bundan sonra (esirleri) ya karşılıksız ya da fidye karşılığı salıverin. Savaş sona erinceye kadar hüküm budur. Eğer Allah dileseydi, onlardan öç alırdı. Fakat sizi birbirinizle denemek için böyle yapıyor. Allah yolunda öldürülenlere gelince, Allah onların amellerini asla boşa çıkarmayacaktır."

142 Kurtubî, el-Câmî‘ li-Ahkâmi'l-Kur'ân, X, 110. 
Süddî’nin, muhkem olduğu açık olan ayetler arasında nâsih-mensûh ilişkisi kurduğuna dair rivayetler de nakledilmiştir. Misal olarak, "Ey iman edenler! Allah'tan, O'na yaraşır şekilde korkun ve ancak müslümanlar olarak can verin." ${ }^{43}$ mealindeki Âl-i 'İmrân suresi 102 . ayetin, "O halde gücünüzün yettiği kadar Allah'tan korkun, dinleyin, itaat edin, kendi iyiliğinize olarak harcayın."144 ayeti ile nesh edildiği Süddî'den rivayet edilmiştir. ${ }^{145} \mathrm{Bu}$ iki ayeti nâsih-mensûh ilişkisi içerisinde değerlendiren tek kimse Süddî olmamakla birlikte bu ayetlerin muhkem olduğunu ve birbirleri arasında nesh irtibatı kurulamayacağı görüşünde olan âlimler de bulunmaktadır. ${ }^{146}$

\subsubsection{Müteşâbih}

Süddî'nin müteşâbih konusuna olan yaklaşımı, Âl-i İmrân suresi 7 . ayet ${ }^{147}$ hakkında kendisinden yapılan nakillerde karşımıza çıkmaktadır. Müteşabih konusunu nâsih-mensûh bağlamında değerlendiren Süddî, ayetlerin müteşabih olanlarına tâbî olan kimselerin, kalplerinde haktan sapma duygusu bulunanlar olduğunu ve onların nesh eden ve nesh edilen ayetlerle ilgili olarak, "Niçin nesh eden ayet gelinceye kadar, nesh edilen ayetle amel edildi, sonra o bırakıldı ve nesh eden ayetle amel edilmeye başlandı? Önceden gelip de nesh edilen ayetle amel etmek yerine, baştan itibaren nesh eden ayetle amel edilmiş olsaydı daha iyi olmaz mıydı? Buna göre Kur'ân'da bir yerde geçen bir ayetle amel eden kişi cehennem azabına uğratılmakla tehdit edilmekte, başka bir yerde zikredilen bir ayette aynı ameli işleyen kimseye ise herhangi bir azap vacib olmamaktadır. Bu nasıl olur?" dediklerini ve bu şekilde insanları doğru yoldan saptırmaya çalıştıklarını söylemektedir. ${ }^{148}$ Süddî’ye göre ayette bahsedilen fitneden maksat şirk ${ }^{149}$, onun te'vilinin peşine düşmekten kasıt ise bazı kimselerin nesh edici son hükümler gelmeden önce onların

\footnotetext{
143

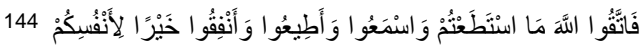

145 Taberî, Câmiu'I-Beyân, V, 642.

146 İbnü'l-Cevzî, Nâsihu'l-Kur'ân ve Menâsihuhu, s. 328-332.

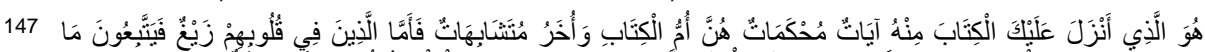

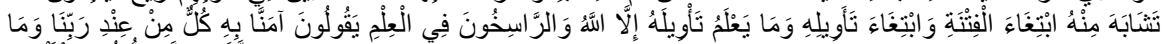
“O, sana Kitab'ı indirendir. Onun (Kur'an'ın) bazı ayetleri muhkemdir, onlar kitabın anasıdır. Diğerleri de müteşâbihtir. Kalplerinde bir eğrilik olanlar, fitne çıkarmak ve onun olmadık yorumlarını yapmak için müteşâbih ayetlerinin ardına düşerler. Oysa onun gerçek manasını ancak Allah bilir. llimde derinleşmiş olanlar, 'Ona inandık, hepsi Rabbimiz katındandır.' derler. (Bu inceliği) ancak akıl sahipleri düşünüp anlar."

148 Taberî, Câmiu'-Beyân, V, 205.

149 Taberî, Câmiu'I-Beyân, V, 212.
} 
ne zaman geleceklerini bilmeye çalışmalarıdır. ${ }^{150}$ Ayette bahsedilen ilimde derinleşmiş olan kimseler ise Süddî'ye göre müminlerdir. Zira onlar nâsih olsun, mensûh olsun Rableri katından indirilen her şeye iman eden kimselerdir. ${ }^{151}$ Süddî'nin muhkem ve müteşâbih ayetleri nesh konusu ile ilişkilendirmesi, İbn Abbas ile yakın bir ilişki içerisinde olmasına bağlanabilir. Zira İbn Abbas'tan nakledilen "Muhkemler nâsih, helal, haram, hudud, feraiz, iman edilip amel edilen; müteşabihler ise mensûh, mukaddem, muahhar, emsâl, yeminler, iman edilip amel edilmeyen hususlardır."152 rivayeti o dönemde müteşabih ve nesh kavramları arasında bir irtibat kurulduğunun göstergesidir. Bununla birlikte erken dönem rivayetlerinde geçen nesh kavramının, usûlcülerin daha sonra bu kavrama yükledikleri ve yukarıda zikrettiğimiz tanımdan çok daha geniş bir kapsamda kullanıldığını da belirtmek gerekir. ${ }^{153}$ Muhtemeldir ki Süddî, nesh konusu hakkında kafa karıştırıcı sorular soran kimseleri Âl-i İmrân suresi 7. ayette fitne çıkarmak isteyenlerle ilişkilendirerek bu yorumda bulunmuştur.

\subsection{9. İsrâiliyyât}

Tefsir literatüründe isrâiliyyât kavramı; tefsire girmiş olan, özellikle Yahudi, Hıristiyan ve diğer dinlere ait kültür kalıntılarıyla, dinin gerek lehine gerekse aleyhine uydurulup $\mathrm{Hz}$. Peygamber'e ve onun muasırları olan sahabe ve müteakip nesillere izafe edilen her türlü haberi içermektedir. Kısa bir ifade ile İslam'a yabancı olan her şey bu kavram bünyesinde değerlendirilebilir. ${ }^{154}$

Süddî'nin tefsirine baktığımızda, onun da isrâiliyyâta dair rivayetleri çok miktarda zikrettiğini görürüz. Süddî'nin yaptığı bu rivayetler genellikle peygamber kıssaları, geçmiş kavimler ve Kur'ân'da geçen bazı özel isimlerle ilgili rivayetlerdir. İsrâilî kaynaklı haberlerin bu konular hakkında nakledilmesi, Tevrat, İncil ve Kur'ân'da bilhassa bu konular üzerinde ortak anlatımların bulunmasıdır. Kur'ân veciz üslûbu gereği bu konular hakkında tafsilata girmeden, sadece vereceği mesaj odaklı bir anlatım yaparken Tevrat ve İncil'de bu konulara dair uzun ve detaylı açıklamalar bulunmaktadır. ${ }^{155}$ Kur'ân ayetlerinin

\footnotetext{
150 Taberî, Câmiu'I-Beyân, V, 215.

151 Taberî, Câmiu'l-Beyân, V, 224.

152 Suyûtî, el-Itkân, III, 4.

153 Bu konu ile ilgili olarak bkz. Aydın, Muhammed, Genel Tefsir Kuralları, Nûn Yayıncılık, İstanbul, 2009, s. 137-139; Dinç, Ömer, Hicri “ilk Üç Asır Bağlamında Nesh Meselesinin Tarihî Süreci Üzerine Bir Tahlil Değerlendirmesi”, III. Türkiye Lisansüstü Çalışmalar Kongresi Bildiriler Kitabı - I (Sosyoloji-Ilahiyat-Eğitim) 15-18 Mayıs 2014, Sakarya, 2014, s. 208.

154 Aydemir, Abdullah, Tefsirde İsrâiliyyât, Beyan Yayınları, İstanbul, 2000, s. 29.

155 Aydemir, Tefsirde Isrâiliyyât, s. 74.
} 
teker teker tefsir edilmeye başlandığı tâbiûn döneminde, hakkında Hz. Peygamber ve sahâbîden herhangi bir nakil bulunmayan bu mevzularda Ehl-i Kitap'tan gelen nakiller de kullanılmış ve isrâiliyyât olarak tabir edilen nakiller İslâmî kaynaklara girmeye başlamıştır Bu dönemde yaşayan bir kimse olarak Süddî'nin de bu rivayetleri kullanması doğal karşılanabilir. Onun yaptığı isrâilî rivayetlere örnek olarak şunları gösterebiliriz:

"Allah, dedi ki: "Birbirinizin düşmanı olarak inin (oradan)."156 ayetinde muhatap, Süddî'den gelen nakle göre Adem, Havva ve yılandır. Allah yılana lanet etmiş, onun ayaklarını koparmış, onu karnı üzerinde sürünmeye mahkûm etmiş ve ona yiyecek olarak toprak takdir edilmiştir. ${ }^{157}$

"Bize bir hükümdar gönder de Allah yolunda savaşalım"158 ayeti hakkında Süddî, Allah'ın İsrailoğullarının bu dualarına karşııı Şimon'u gönderdiğini söylemiş ${ }^{159 ;}$ "Allah kendisine mülk verdi diye İbrahim ile Rabbi hakkında tartışanı görmedin mi?"160 ayetinde de bu tartışmayı yapan kimsenin Nemrut olduğu'161, Furkân suresi 38. ayette ${ }^{162}$ kendilerinden bahsedilen 'Ress Ashabı'nın da Antakya ehli, 'Ress'in ise Antakya'da bulunan bir kuyu olduğu ve bu kavmin Habîb en-Neccâr'ı öldüren kavim oldukları kendisinden rivayet edilmiştir. ${ }^{163}$

Sâd suresi 21-24. ayetlerin tefsirinde Sûyûtî'nin Süddî'den naklettiğine göre Hz. Dâvud evinin çatısında yıkanan bir kadın görmüş, güzelliğinden etkilenerek onu soruşturmuş, evli olduğunu öğrenince kocasını peş peşe savaşlara göndermiş ve kocası bu savaşlardan birinde ölünce onu nikâhlamıştır. ${ }^{164}$ Taberî de Sâd suresi 34. ayette Hz. Süleyman'ın imtihana tâbî tutulması hakkında Süddî'den bir rivayet nakletmiştir. Buna göre şeytan, Hz. Süleyman'ın suretine bürünerek onun yüzüğünü emanet ettiği hanımına yaklaşarak yüzüğü ele geçirmiş, böylece $\mathrm{Hz}$. Süleyman kırk gün süreyle hükmünü kaybetmiştir. ${ }^{165}$

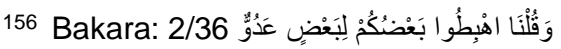

157 Taberî, Câmiưl-Beyân, I, 572. Ayrıca bkz. Eski Ahid, Tekvin, 3/14.

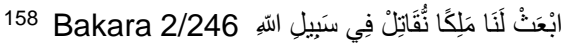

159 Taberî, Câmiuł-Beyân, IV, 436; Kurtubî, el-Câmî‘ li-Ahkâmi'l-Kur'ân, IV, 228; Suyûtî, ed-Dürrül-Mensûr, III, 135.

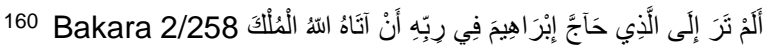

161 Taberî, Câmiu'I-Beyân, IV, 575.

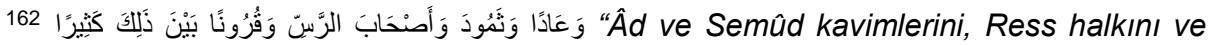
bunların arasında pek çok nesilleri de helâk ettik."

163 Kurtubî, el-Câmî' li-Ahkâmi'l-Kur'ân, XV, 411.

164 Suyûtî, ed-Dürrü'l-Mensûr, XII, 533.

165 Taberî, Câmiu'I-Beyân, XX, 91.
} 
İbrahim en-Nehâînin (v. 96/714) Süddî̀yi, halkın bildiğine benzer bilgilerle tefsir yapmakla itham etmesinin ${ }^{166}$, Şa'bî̀nin ona, "Makadına tokmak ile vurulması, senin burada oturmandan (tefsir dersi yapmandan) daha hayırlıdır ${ }^{167}$ demesinin, yine Süddî̀ye Kur'ân ilminden bir pay verildiğini söyleyen bir kimseye Şa'bî'nin, "Ona Kur'ân'ın cehaletinden bir pay verilmiştir." diyerek cevap vermesinin ${ }^{168}$, onun tefsir yaparken isrâiliyat kabilinden bu tür peygamberlerin sıfatları ve İslam düşüncesi ile bağdaştıııması mümkün olmayan haberleri kullanması ile ilişkili olduğu düşünülebilir. Öyle ki Hudayrî de onun, Kûfe medresesinde yetişmesine rağmen bu ekolün yöntemine aykırı olarak Ehl-i kitaptan çok sayıda nakilde bulunduğu ve bu konuda son derece müsamahakâr olduğunu belirtmiştir. ${ }^{169}$ Tedvîn döneminde isrâiliyyâtın yoğun bir şekilde İslam kaynaklarına girdiği bir vâkıadır. Bununla birlikte bu bilgileri kullanan kimselerin, onları hangi bağlamda kullandıkları bilinmemektedir. Bu rivayetlerin gerçekten bir bilgi olarak kabul edilip nakledilmiş olabileceği gibi, misal olarak yahut kıyas yapma amacıyla zikredilmiş olabileceği, hatta nakledildikten tenkid edilmiş olabileceği de göz önünde bulundurulmalıdır.

\section{Sonuç}

İslam dininin Arabistan sınırlarını aşarak farkı dil ve kültürlere sahip toplumlar arasında da yayılmaya başlaması bilhassa tâbiîler dönemine denk düşmektedir. Bu dönemde tabiîler gerek kendi beldelerine gelen sahabîlerden ders alarak gerekse kendileri İslam'ı öğrenmek için ilim öğrenme amaçlı seyahatler yaparak ashabtan Kur'ân ve Hz. Peygamber'in sünnetine dair bilgileri öğrenmişler ve bilhassa hadis ve tefsir ilminin tedvin edilmesine önayak olmuşlardır. Hicaz'da doğan ve Irak'ta vefat eden Süddî de yaptığı tefsir nakilleriyle ashabtan ve çağdaşı tâbiîlerden aldığı bilgileri bazen naklederek bazen de yorumlayarak sonraki nesillere aktarmış önemli bir şahsiyettir. Her ne kadar hakkında bazı menfi haberler verilmiş ve kendisinin yaptığı rivayetlerin güvenilirliği hakkında bir ittifak sağlanamamış olsa da hadis ilminde otorite kabul edilen Buhârî, Ahmed b. Hanbel, Şu'be b. Haccâc ve Süfyân es-Sevrî gibi kimselerin ondan nakillerde bulunması Süddînin güvenilirliği hususunda bize önemli bir ipucu vermektedir. Bazı kaynaklarda onun Şîi yahut Şiâ'ya yakın olduğuna dair haberler bulunsa da kendisinden gelen rivayetlere bakıldığında Süddî ile Şîa arasında organik bağ kuracak açık bir delil bulunma-

\footnotetext{
166 İbn Ebî Hâtim, el-Cerh ve't-Ta'dîl, II, 184.

167 Taberî, Câmiu'l-Beyân, I, 87.

168 Ahmed b. Hanbel, Ebû Abdullah Ahmed b. Muhammed eş-Şeybânî, el-'ilel ve Ma'rifetürr-Ricâl, thk. Vasiyyullah b. Muhammed Abbâs, Dâru'l-Hânî, Riyad, 1422, II, 334.

169 Hudayrî, Muhammed b. Abdullah b. Ali, Tefsîru't-Tabiîn, Dâru'l-Vatan, Riyad, 1990, I, 305.
} 
maktadır. Kûfeliler arasında tefsire dair en çok rivayette bulunan kimseler arasında gösterilmesi de onu tefsir ilmi açısından önemli kılmaktadır. Kaynaklarda kendisine ait tam bir tefsir bulunduğuna dair haberler yer alsa da günümüze ulaşan bu mahiyette bir eser tespit edilememiştir. Süddî'den gelen tefsir rivayetleri karşımıza, başta Taberî ve İbn Kesîr olmak üzere farklı tefsirlerde dağınık bir halde bulunmaktadır.

Süddî'den gelen rivayetler ışığında onun tefsir yöntemi incelendiğinde onun, Kur'ân'ı anlamanın en temel yöntemleri olarak addedilebilecek Kur'ân'ın Kur'ân ve sünnet ile tefsirinden sıklıkla yararlandığı görülmektedir. Diğer yandan onun, ayetleri açıklarken nüzul sebeplerini zikrettiği ve çeşitli tarihi bilgilerden yararlandığı da görülmektedir. Şer'î hükümler konusunda Süddî zaman zaman ayet ve hadisleri delil olarak kullanırken kimi zaman da re'y ve ictihad ile hüküm istinbat etmiştir. Nesh konusunda Kur'ân'da neshin varlığını kabul eden tarafta yer alan Süddî, müteşabih konusunu da nesh bağlamında değerlendirmiş, müteşabih ayetlerin te'vilinin peşine düşenleri nâsih son hükümler gelmeden önce onların ne zaman geleceklerini bilmeye çalışanlar, ilimde derinleşmiş olanları ise nâsih olsun, mensûh olsun Rableri katından indirilen her şeye iman eden müminler olarak değerlendirilmiştir. Süddî'den gelen tefsir rivayetlerinde belki de en çok tenkide tabi tutulan husus, onun isrâiliyyât kabilinden haberlere sıklıkla yer vermesidir. Öyle ki Süddî bazen peygamberlik görevine yakışmayacak vasıfları onlara isnad eden haberleri de ayetlerin tefsirinde kullanmıştır. Bu durum sadece Süddî'ye has bir durum değildir. Kur'ân ayetlerinin teker teker ele alınarak tefsir edilmeye başlandığı tâbiîn döneminde, hakkında Hz. Peygamber'den bir rivayet yahut ashabtan bir bilgi ulaşmayan ayetler için isrâiliyyât olarak isimlendirilen bilgilerin kullanıldığı pek çok tefsir eseri bulunmaktadır. 


\section{Kaynakça}

Ahmed b. Hanbel, Ebû Abdullah Ahmed b. Muhammed eş-Şeybânî, el-'ilel ve Ma'rifetü'r-Ricâl, thk. Vasiyyullah b. Muhammed Abbâs, Dâru'l-Hânî, Riyad, 1422.

Albayrak, Halis, Tefsir Usûlü, Şule Yayınları, İstanbul, 1998.

Âlûsî, Şihabuddin Mahmud, Rûhu'l-Me'ânî fî Tefsîri'l-Kur'ani'l-Azîm ve'sSeb ‘'l-Mesânî, Dâru İhyâi't-Turâsi'l-Arabî, Beyrut, t.y.

Aydemir, Abdullah, Tefsirde İsrâiliyyât, Beyan Yayınları, İstanbul, 2000.

Aydın, Muhammed, Genel Tefsir Kuralları, Nûn Yayıncılık, İstanbul, 2009.

Bilmen, Ömer Nasuhi, Büyük Tefsir Tarihi: Tabakâtü'l-Müfessirîn, Bilmen Yayınevi, İstanbul, 1973.

Buhârî, Ebû Abdullah Muhammed b. İsmail, et-Târîhu'l-Kebîr, Dâiretü'lMeârifi'l-Osmâniyye, Haydarabad, t.y.

Cerrahoğlu, İsmail, Tefsir Usûlü, Türkiye Diyanet Vakfı Yayınları, Ankara, 1993.

-, "Süddî", Türkiye Diyanet Vakfı İslam Ansiklopedisi, Türkiye Diyanet Vakfı Yayınları, İstanbul, 2010.

Cevherî, Ebû Nasr İsmâîl b. Hammâd, es-Sıhâh Tâcu'l-Lüga ve Sıhâhi'lArabiyye, thk. Ahmed Abdulgafûr Attâr, Dâru'l-İlm li'l-Melâyîn, Beyrut, 1987.

Cürcânî, Seyyid Şerîf, et-Ta'rîfât, Dâru'l-Kütübi'l-IIImiyye, Beyrut, 1983.

Cürcânî, Ebû Ahmed Abdullah b. Adî, el-Kâmil fî Du'afâi'r-Rical, thk. Yahyâ Muhtâr Gazâvî, Dâru'l-Fikr, Beyrut, 1988.

Cuzcânî, İshak İbrâhim b. Yakub b. İshak es-Sa'di, Ahvâlü'r-Ricâl, thk. Subhî el-Bedrî Samerraî, Müessesetü'r-Risâle, Beyrut 1985.

Demirci, Muhsin, Tefsir Usûlü, Marmara Üniversitesi İlahiyat Fakültesi Vakfı Yayınları, 3. bs, İstanbul, 2003.

-----------, Tefsir Tarihi, Marmara Üniversitesi İlahiyat Fakültesi Vakfı Yayınları, İstanbul, 2003.

Dinç, Ömer, Hicri "ïlk Üç Asır Bağlamında Nesh Meselesinin Tarihî Süreci Üzerine Bir Tahlil Değerlendirmesi”, III. Türkiye Lisansüstü Çalışmalar Kongresi Bildiriler Kitabı - I (Sosyoloji-İlahiyat-Eğitim) 15-18 Mayıs 2014, Sakarya, 2014, ss. 203-219.

Duman, M. Zeki, "Tabiûn Döneminde Tefsir Faaliyeti (Meşhur Müfessirler, Kaynakları ve Bu Tefsirin Değeri)", Erciyes Üniversitesi İlahiyat Fakültesi Dergisi, sayı: 4, 1987, ss. 209-238.

Fîruzâbâdî, Ebu't-Tahir Mecdüddîn Muhammed b. Ya‘kûb b. Muhammed, elKâmûsu'l-Muhît, Müessesetü'r-Risâle, Beyrut, 2005. 
Halîf, Yusuf, Hayatü'ş-Şi'r fi'l-Kûfe ila Nihâyeti Karni's-Sâni li'l-Hicre, Dâru'lKitâbi'l-Arabî, Kahire, 1968.

Hamevî, Ebû Abdullah Şihâbuddîn Yâkût b. Abdullah Yakut, Mu'cemu’lUdebâ, thk. İhsân Abbâs, Dâru'l-Garbi'l-İslâmî, Beyrut, 1993.

Hazrecî, Ahmed b. Muhammed, Hulasatu Tezhîbi Tehzîbi'l-Kemâl fî Esmâi'rRicâl, thk. Abdulfettâh Ebû Gudde, Mektebetü'l-matbûâti'l-islâmiyyeDâru'l-Beşâir, Haleb-Beyrut, 1416.

Hindî, Alâüddîn Alî b. Müttakî b. Hüsâmüddîn el-Bürhanfûrî, Kenzü'l-'Ummâl fî Süneni'l-Akvâl ve'l-Ef'âl, thk. Bekrî Hayyânî, Safvet es-Sekâ, Müessesetü'r-Risâle, Beyrut, 1981.

Hudayrî, Muhammed b. Abdullah b. Ali, Tefsîru't-Tabiîn, Dâru'l-Vatan, Riyad, 1990.

İbn Abdilber, Ebû Ömer Cemaleddîn Yûsuf b. Abdullah b. Muhammed Kurtubî, el-İsti'âb fî Ma'rifeti'l-Ashâb, thk. Ali Muhammed Bicâvî, Dâru'l-Cîl, Beyrut, t.y..

İbnü'l-Cevzî, Abdurrahman b. Ali b. Abdullah, Nâsihu'l-Kur'ân ve Menâsihuhu, el-Câmiatü'l-İslâmiyye, Medine, 2003.

İbnü'l-Cezerî, Şemseddin Ebu'l-Hayr Muhammed b. Muhammed, Müncidü'lMukri'în ve Mürşidü't-Tâlibîn, Dâru'l-Kütübi'I-İlmiyye, Beyrut, 1999.

İbn Cüzeyy, Ebu'l-Kâsım Muhammed b. Ahmed b. Muhammed el-Kelbî elGırnatî, et-Teshîl li 'Ulûmi't-Tenzîl, thk. Rıza Ferec el-Hümâmî, Mektebetü'l-Asriyye, Beyrut, 2005.

İbn Düreyd, Ebû Bekr Muhammed b. el-Hazm el-Ezdî el-Basrî, Kitâbu Cemherati'l-Luga, thk. Remzi Münîr Ba'lebekî, Dâru'l-İlm li'l-Melâyîn, Beyrut, 1987.

İbn Ebî Hâtim, Ebû Muhammed Abdurrahman b. Muhammed b. İdrîs, elCerh ve't-Ta'dîl, Dâru'l-Kütübi'l-İlmiyye, Beyrut, t.y., [Dâru'l-Meârifi'lOsmâniyye, Haydarâbad, 1952'nin ofseti.]

İbnü'l-Esîr, Ebu'l-Hasan İzzeddin Ali b.Muhammed b.Abdülkerim, el-Lübab fî Tehzibi'l-Ensâb, Dâru Sâdır, Beyrut, t.y.

İbn Hacer Askalânî, Ebu'l-Fazl Şihâbuddîn Ahmed, Lisânü'l-Mîzân, Müessesetü'l-A'lemî li'l-Matbûât, Beyrut, 1971.

---------, Tehzîbu't-Tehzîb, Dâru'l-Fikr, Beyrut, 1984.

İbn Hazm, Ebû Muhammed b. Ali b. Ahmed b. Saîd ez-Zahiri, en-Nâsih ve'lMensûh fi'l-Kur'âni'l-Kerîm, thk. Abdulgaffâr Süleyman Bündârî, Dârü'lKütübi'l-İlmiyye, Beyrut, 1986.

İbn Hibban, Ebû Hâtim Muhammed b. Hibban b. Ahmed et-Temîmî, Meşahiru Ulemai'l-Emsâr, thk. Marzûk Alî İbrahim, Dâru'l-Vefâ, Mansûre, 1991. 
İbn Kesîr, Ebû'l-Fidâ İsmâil b. Kesîr el-Kuraşî, Tefsîru'l-Kur'âni'l-Azîm, thk. Sâmî b. Muhammed es-Sellâme, Dâru Tayyibe, Riyad, 1999.

İbn Kuteybe, Ebû Muhammed Abdullah b. Müslim b. Kuteybe Dîneverî, elMaârif, thk. Servet Ukkâşe, Heyetü'l-Mısriyyeti'l-Amme li'l-Kitâb, Kahire, 1992.

İbn Mâkûlâ, Ebû Nasr Sa'dülmelik Ali b. Hibetullah b. Ali, el-likmal fî Refi'lIrtiyab ani'l-Mü'telif ve'l-Muhtelif mine'l-Esma ve'l-Küna ve'l-Ensâb, Dâru'l-Kütübi'l-IIlmiyye, Beyrut, 1990.

İbn Manzûr, Ebu'l-Fazl Cemâluddîn Muhammed b. Mükerrem el-lfrikî, Lisânü'l-'Arab, Dâru Sâdır, Beyrut, t.y.

İbn Mücâhid, Ebû Bekr Ahmed b. Musa b. Abbas et-Temîmî, Kitâbu’s-Seb‘a fi'l-Kırâât, Dâru'l-Maârif, Kahire, 1972.

İbnü'n-Nedîm, Muhammed b. İshak Ebu'l-Ferec, el-Fihrist, thk. İbrahim Ramazan, Dâru'l-Ma'rife, Beyrut, 1997.

İbn Tağrîberdî, Cemaleddin Ebi'l-Muhasin Yûsuf el-Atabekî, en-Nücûmu'zZahira fî Mülûkü Mısr ve'l-Kâhira, Kahire, 1963.

İbn Teymiyye, Ebu'l-Abbas Takıyyüddîn Ahmed b. Abdulhalîm, Mukaddime fî Usûli't-Tefsîr, Dâru Mektebeti'l-Hayât, Beyrut, 1980.

İsfahânî, Ebû Nuaym Ahmed b. Abdullah b. İshak, Kitâbu Târîhi İsbahan: Zikru Ahbâri İsbahan, thk. Seyyid Kisrevî Hasan, Dâru'l-Kütübi'l-İlmiyye, Beyrut, 1990.

Kayrevânî, Ebû Alî Hasen b. Reşîk Ezdî İbn Reşîk, el-'Umde fî Mehâsini’ş-Şi'ri ve Âdâbih, thk. Muhammed Muhyiddîn Abdulhamîd, Dâru'l-Cîl, Beyrut, 1981.

Kazvinî, Ebû Ya'la el-Halil b. Abdillah b. Ahmed el-Halîlî, el-İş̧âd fî Ma'rifeti Ulûmi'l-Hadîs, Riyad, Mektebetü'r-Rüşd, 1989.

Kurtubî, Ebû Abdurrahman Muhammed b. Ahmed b. Ebî Bekr, el-Câmî‘ liAhkâmi'l-Kur'ân, thk. Abdullah b. Abdulmuhsin et-Türkî, Müessesetü'rRisâle, Beyrut, 2006.

Mervezî, Ebû Sa'd Abdülkerim b. Muhammed b. Mansur Sem‘ânî, el-Ensâb, Dâiretü Maârifi'l-Osmâniyye, Haydarâbâd, 1962.

Mizzî, Ebu'l-Haccac Cemaleddin Yusuf b. Abdurrahman b. Yusuf, Tehzibü'lKemâl fî Esmâi'r-Ricâl, thk. Beşşâr Avvâd Ma'rûf, Müessesetü'r-Risâle, Beyrut, 1980.

Muhammed 'Atâ Yûsuf, Tefsîru's-Süddî el-Kebîr, Dâru'l-Vefâ, Mansûre, 1993. Muhsin Emin, Ebu Muhammed Seyyid Muhsin b. Abdilkerim b. Ali, A‘yânü'şŞî‘a, Dâru’t-Taarruf li’l-Matbûât, Beyrut, 1983. 
Müslim, Ebû Huseyn Müslim b. Haccâc el-Kuşeyrî, Sahîh, Dâru Tayyibe, Riyad, 1426.

Sehavî, Ebu'l-Hasan Alemuddîn Ali b. Muhammed b. Abdüssamed, Cemalü'lKurrâ ve Kemâlu'l-Ikrâ', Müessesetü'l-Kütübi's-Sekâfiyye, Beyrut, 1999.

Sezgin, Fuad, Târîhu't-Turâsi'l-Arabî, İdâretü's-Sekâfeti ve'n-Neşr bi'l-Câmia, Riyad, 1991.

Suyûtî, Celâleddîn, ed-Dürrü'l-Mensûr fi't-Tefsîr bi'l-Me'sûr, thk. Abdullah Abdilmuhsin et-Türkî, Merkezi Hicr li'l-Buhûs ve'd-Dirâseti'l-Arabiyye ve'lİslâmiyye, Kahire, 2003.

----------, el-itkân fî 'Ulûmi'l-Kur'ân, thk. Muhammed Ebu'l-Fadl İbrahim, elMektebetü'l-'Asriyye, Beyrut, 1997

Şevkânî, Muhammed Ali b. Muhammed, Fethu'l-Kadîr, thk. Abdurrahman Umeyre, Daru'l-Vefâ, Mansûre, 1994.

Taberânî, Ebu'l-Kâsım Süleyman b. Ahmed b. Eyyûb el-Lahmî, Mu'cemu'lKebîr, thk. Hamdi b. Abdulmecîd es-Selefî, Mektebetü İbn Teymiyye, Kahire, 1994.

Taberî, Ebû Cafer İbn Cerîr Muhammed b. Cerîr b. Yezîd, Câmiu'l-Beyân fî Tefsiri'l-Kur'ân, thk. Abdullah b. Abdulmuhsin et-Türkî, Dâru Hicr li'tTıbâa ve'n-Neşr, 2001.

Turgay, Nurettin, “Tabiunun/Tabiilerin Tefsir İlmindeki Yeri”, Bilimname, 2010/1, cilt: VIII, sayı: 18, ss. 93-114

Vâhidî, Ebu'l-Hasan Ali b. Ahmed b. Muhammed en-Nisâbûrî, Esbâbü'nNüzûl, thk. Kemâl Besyûnî Zağlûl, Dâru'l-Kütübi'l-İlmiyye, Beyrut, 1991.

Zebîdî, Muhammed Murtaza el-Huseynî, Tâcu'l-'Arûs min Cevâhiri'l-Kâmûs, thk. Abdulazîz Matar, 2. bs., Kuveyt, 1994.

Zehebî, Ebû Abdullah Şemseddîn Muhammed b. Ahmed b. Osman, Mîzânü’lI'tidâl fî Nakdi'r-Ricâl, Dâru'l-Kütübi'l-İlmiyye, Beyrut, 1995.

Zürkânî, Muhammed Abdülazîm, Menâhilü'l-Irfân fî 'Ulûmi'l-Kur'ân, thk. Fevvâz Ahmed Zemerlî, Dâru'l-Kitâbi'l-Arabî, Beyrut, 1995. 


\section{Suddi al Kebir as an Exegete}

Citation / (C-Denizer, N. (2017). Suddi al Kebir as an Exegete, Çukurova University Journal of Faculty of Divinity, 17 (1), 357-388.

Abstract- From the moment when the Qur'an begins to be revealed, teaching and explaining the necessary parts of verses was started by Prophet himself. After Prophet Muhammad's (s.a.a.w) demise, first muslim generations transferred informations that they have learned from The Prophet to the second muslim generations by transfering the verbal information directly and interpreting it. The second generations era is a period that different problems and questions had emerged due to the expansion of Islamic lands rising, increasing the number of Muslims from different cultures and nations. Accordingly different approaches have arised in understanding and interpreting The Quran. In this period, the educators raised in the Tafsir medreseses that are established in Mecca, Medina and Kufah began to separate from each other, developed different ideas and methods of understanding and applying the Qur'an in the light of the information they receive from the companions. In additon, information about Tafsir began to be copyrighted as separated leaflets in this period. Suddî al-Kebir is also one of the prominent figures of second muslim generations who was born in Hijaza and lived in Qufa, and who led many commentaries on and later hermenetics. Although there are references to a source of a complete commentary attributed to Suddi who referring to Ibn Abbas and Ibn Mas'ûd mostly, there is no work of this quality that reaches the present day. Narrative Tafsir comments by Suddi are found in narrated comments discursively. When these narrations are examined, he uses exegesis by means of the qoran and sunnah method and he also uses evelatory occasions and historical information and accordingly made out some religious judgements, he expresses opinions about naskh and mutashabih. Suddi was criticised strongly for giving wide coverage to Israiliyyat. In this study, Süddî's life, scientific direction and claims about him to be Shiitel will be evaluated and his tafsir method and commentary direction will be tried to be expressed.

Keywords- Commentary, narrated commentary, method, Suddi 